\title{
Volcanic ash in bare ice south of Sør Rondane Mountains, Antarctica: geochemistry, rock magnetism and nondestructive magnetic detection with SQUID gradiometer
}

\author{
Hirokuni Oda ${ }^{* *}$ D, Isoji Miyagi ${ }^{2}$, Jun Kawai ${ }^{3}$, Yusuke Suganuma ${ }^{4}$, Minoru Funaki ${ }^{4}$, Naoya Imae ${ }^{4}$, \\ Takashi Mikouchi ${ }^{5}$, Takuya Matsuzaki ${ }^{6}$ and Yuhji Yamamoto ${ }^{6}$
}

\begin{abstract}
Nondestructive magnetic detection of tephra layers in ice cores will be an important method to identify and correlate stratigraphic horizons of ice bearing volcanic ash particles. Volcanic ash particles were extracted from tephra-bearing ice samples collected from Nansen Ice Field south of the Sør Rondane Mountains, Antarctica. Particles are fresh glassy volcanic ash with diameters of $\sim 50 \mu \mathrm{m}$, and chemical composition of the matrix glass belongs to a low-K basaltic andesite group, ranging from $\mathrm{SiO}_{2} 60-62 \mathrm{wt} \%$ and $\mathrm{K}_{2} \mathrm{O} 0.40-0.50 \mathrm{wt} \%$. Considering the grain size of ash particles and chemical composition of volcanic glass, the ash in tephra-bearing ice samples might be originated from the South Sandwich Islands located $2800 \mathrm{~km}$ northwest of the sampling sites. Correlations on major element concentrations with tephra layers associated with South Sandwich Islands in EPICA-Dome C, Vostok, and Dome Fuji ice cores show high similarity. Rock magnetic experiments show that the magnetic mineral is pseudo-single-domain titanomagnetite with ulvospinel content of 0.2-0.35 mixed with single-domain to superparamagnetic (titano)magnetite. Small blocks of the tephra-bering ice were measured with a SQUID gradiometer at 1-mm intervals with a spatial resolution of $\sim 3 \mathrm{~mm}$. With DC magnetic field of $25 \mathrm{mT}$, magnetic signal could be enhanced and detected for all the samples including the one with invisible amount of tephra particles. In order to simulate a thin ash layer in ice core, volcanic ash particles extracted from the tephra-bearing ice were used to fabricate a thin ash layer, which were subsequently magnetized, measured with the gradiometer. The noise level for $Z$ axis gradiometer was about 0.6 pT. Detection limit for a half-cylinder with $29 \mathrm{~mm}$ radius and a thickness of $1 \mathrm{~mm}$ uniformly magnetized in $X$ axis direction is $\sim 9 \times 10^{-5}$ $\mathrm{A} / \mathrm{m}$, which could be improved down to $\sim 2 \times 10^{-6} \mathrm{~A} / \mathrm{m}$ by reducing the sensor-to-sample distance to $0.5 \mathrm{~mm}$.
\end{abstract}

\section{Background}

The importance of ice core records to reconstruct climate in Late Pleistocene to Holocene is increasing for the past decades (e.g., Jouzel 2013). The climate archives of ice in Antarctica and Greenland have been retrieved by ice coring projects such as Dome Fuji (e.g., Watanabe et al. 1999), EPICA-Dome C (e.g., Landais et al. 2012), Vostok (e.g., Bender et al. 2006). Ice cores are archives of

\footnotetext{
*Correspondence: hirokuni-oda@aist.go.jp

${ }^{1}$ Research Institute of Geology and Geoinformation, Geological Survey of Japan, AIST, Central 7, 1-1-1 Higashi, Tsukuba 305-8567, Japan Full list of author information is available at the end of the article
}

waters (records of hydrogen and oxygen isotopes of ice), gases (concentrations and isotopic compositions of oxygen, nitrogen, carbon dioxide, methane, etc.), ions (chlorine, sodium, sulfate, etc.) which deposited on surface, pressed, frozen and encapsuled as archives of long-term climate change and episodic events. Ice cores also contain various solid particles such as eolian dust, volcanic ash and extraterrestrial materials (e.g., Misawa et al. 2010; Okazaki et al. 2015). Volcanic ash could be marker horizons representing events associated with volcanic eruptions in relatively short period of time (typically a year to several years).

\section{贷 Springer}

(C) 2016 Oda et al. This article is distributed under the terms of the Creative Commons Attribution 4.0 International License (http://creativecommons.org/licenses/by/4.0/), which permits unrestricted use, distribution, and reproduction in any medium, provided you give appropriate credit to the original author(s) and the source, provide a link to the Creative Commons license, and indicate if changes were made. 
Sulfur dioxide is extensively emitted at the time of volcanic eruptions as a major component of volcanic gases (e.g., Mori and Kato 2013), which is further transformed into sulfate by oxidation in the atmosphere (e.g., Kroll et al. 2015). High-sensitivity nondestructive magnetic detection of ash layers in ice cores could be an important method to identify stratigraphic horizons of volcanic activities for synchronization combined with electrical conductivity peaks related to sulfate supplied at the time of volcanic eruptions (e.g., Parrenin et al. 2012). Combination of electrical conductivity and magnetic methods will be robust in identification of volcanic eruptions utilizing both gas and solid phases. In particular, large-scale eruption events which may have affected global climate such as Toba supereruption is quite important for the Quaternary paleoclimate and chronostratigraphy (Storey et al. 2012).

Rock magnetic identification of continuous record of terrestrial dust particles and extraterrestrial fallout in ice cores of Greenland and Antarctica was carried out by Lanci et al. (2012). On the other hand, Antarctic ice containing visible ash related to volcanic events is known to be distributed over bare ice areas as tephra-bearing ice layers (e.g., Naraoka et al. 1991). Natural remanent magnetization of tephra-bearing ice layers collected from Antarctica has been studied and was suggested to give stable magnetization with stepwise alternating demagnetization (Funaki and Nagata 1985; Funaki 1990; Funaki and Sakai 1997). Funaki and Sakai (1997) applied saturation isothermal remanent magnetization (SIRM) to the tephra-bearing ice and obtained relatively uniform magnetization within the studied tephra-bearing ice layer of a thickness of $80 \mathrm{~mm}$. Thus, magnetic detection of volcanic ash layers in ice is promising either as natural state or after acquisition of artificial magnetization such as SIRM.

In this study, we report on geochemistry and rock magnetic properties of volcanic ash particles extracted from tephra-bearing ice block samples collected from Nansen Ice Field, Antarctica. The distribution of volcanic ash particles within tephra-bearing ice block samples was also measured with a microfocus X-ray computed tomography (X-ray CT) scanner and presented. Then, the tephra-bearing ice block samples were measured with a three-axis LTS-SQUID gradiometer developed for nondestructive evaluation. The extracted volcanic ash particles were used to construct a thin artificial ash layer of half-circular shape to imitate half-round ice cores and measured with the gradiometer.

\section{Samples}

Tephra-bearing ice samples were collected from Nansen Ice Field south of the Sør Rondane Mountains (72 $30^{\prime}-$ $73^{\circ} \mathrm{S}, 23^{\circ}-25^{\circ} \mathrm{E}$; elevation $2900-3000 \mathrm{~m}$ ), Antarctica
(Fig. 1), during 54th Japanese Antarctic Research Expedition (Imae et al. 2015). Nansen Ice Field is known as one of the major meteorite collection sites in Antarctica providing more than 2500 specimens (Cassidy et al. 1992). Sampling sites are located in the bare ice area where volcanic ash deposited in the past is exposed on surface. Several tephra-bearing ice blocks were taken from each of the three sites (Table 1). The tephra-bearing ice layer was the largest encountered during the expedition extending about $2 \mathrm{~km}$ or more, which could be clearly traced from Site JARE54-ASH1 to Site JARE54-ASH2, and could mostly be traced from Site JARE54-ASH2 to Site JARE54-ASH3. The darker dense part of the tephrabearing ice layer has a thickness of $5-10 \mathrm{~cm}$, which is sharply terminated by bluish clear ice on the northeast side (Fig. 1c, d). The volcanic ash particle distributions may have not been modified significantly by the effect of ablation at the time of deposition or exposure to the surface because the tephra-bearing ice layer could be traced continuously more than several kilometers and could be traced down into the ice at an angle with equal thickness (see Fig. 1d). The whole thickness of the tephra-bearing ice layer including brighter sparse part is about $20 \mathrm{~cm}$ on average. The ice block samples were transported in freezer from Antarctica to National Institute of Polar Research (NIPR) by airplane together with meteorites collected during 54th Japanese Antarctic Research Expedition. Ice block samples were stored in low-temperature storage of $-20^{\circ} \mathrm{C}$ at NIPR. Then, ice block samples were transported $\left(-20{ }^{\circ} \mathrm{C}\right)$ to Kanazawa Institute of Technology (KIT) for the measurements with the gradiometer or to Geological Survey of Japan (GSJ) for the measurements with SQUID magnetometer.

\section{Instruments and methods}

Reflection on surfaces of an ice block is irregular preventing clear visual observation. In order to visualize the 3D distribution of volcanic ash particles in ice, measurements on an ice block sample from each of the three sites (Table 2) were conducted with a microfocus X-ray CT scanner (TESCO Corporation HMX225-ACTIS+3) at the Center for Advanced Marine Core Research (CMCR), Kochi University. The voltage was $120 \mathrm{kV}$, and current was $30 \mu \mathrm{A}$. Pixel size was $30 \times 30 \times 30 \mu \mathrm{m}^{3}$ with $1024 \times 1024$ pixels and 435 slices. Cylindrically shaped container with a lid was made from formed polystyrene, and ice block sample was placed in the upper half of the container on a horizontal support in the middle. Liquid nitrogen $\left(\mathrm{LN}_{2}\right)$ was filled in the lower half of the container to keep the temperature of ice below ice freezing point for more than $10 \mathrm{~min}$. Scanning with X-ray was conducted by rotating the sample in the X-ray radiation chamber for about $5 \mathrm{~min}$. After each scan, the lid was 
a

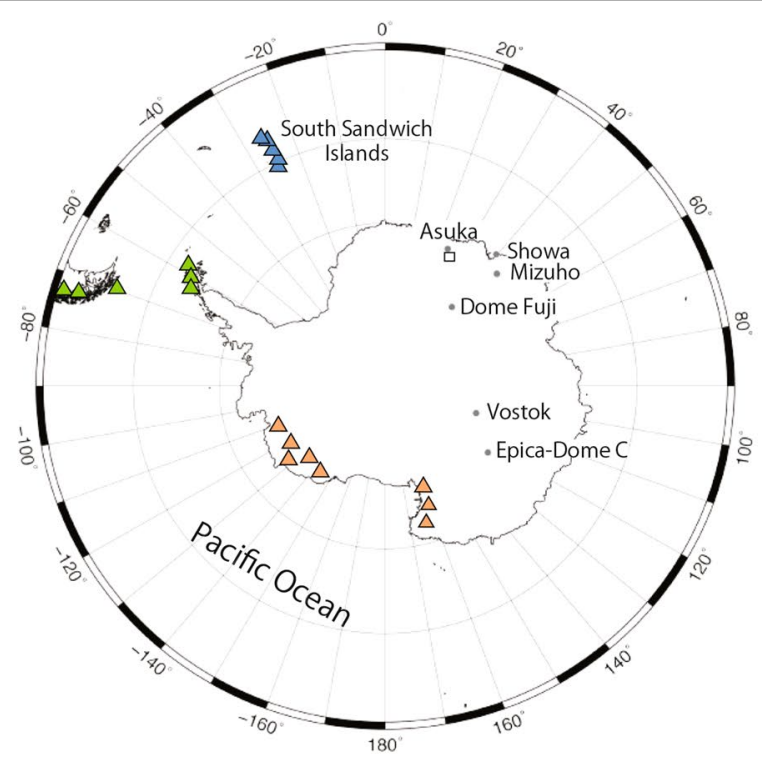

b

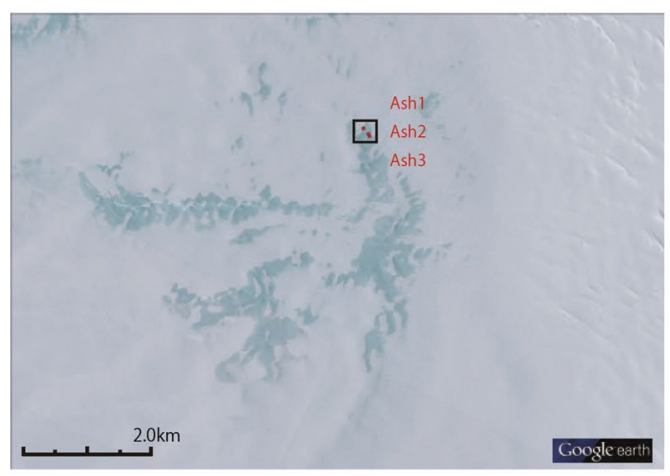

C

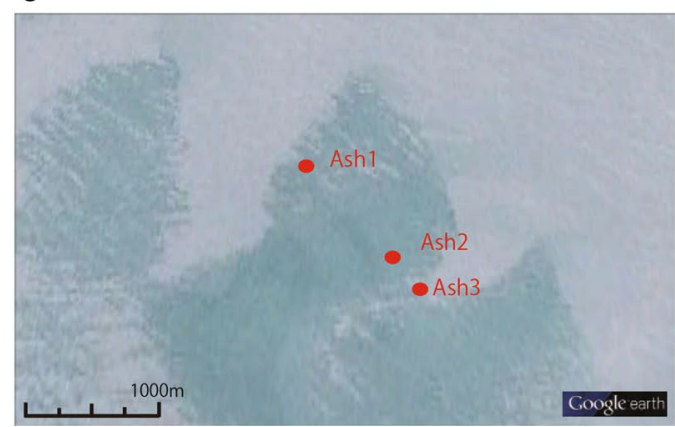

d

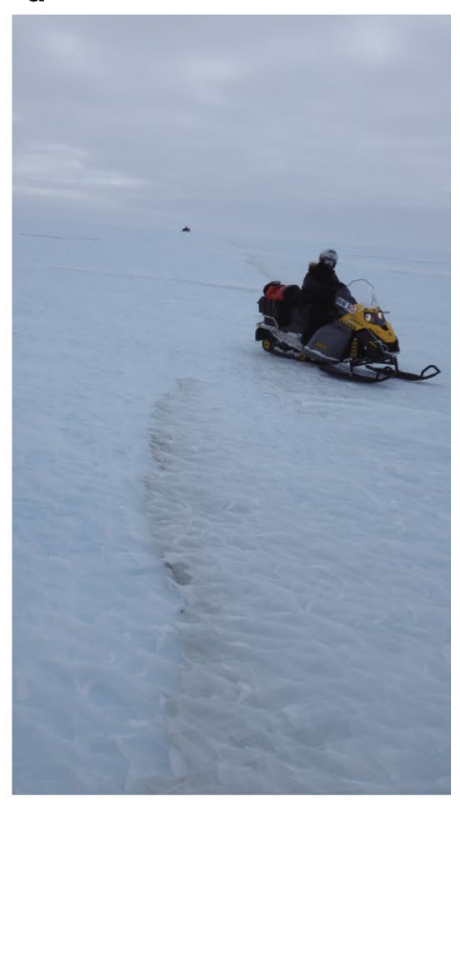

Fig. 1 Location of tephra-bearing ice samples collected from Antarctica. a Map of Antarctica showing sampling areas with names of stations and ice core sites (gray circles). Triangles are volcanic sources reproduced from Narcisi et al. (2010); South Sandwich Islands (blue), South Andes and South Shetland Islands (green) and Marie Byrd Land and McMurdo (orange). b Nansen Ice Field around Sør Rondane Mountains; close-up of the rectangular area shown in (a) south of Asuka Station. Sampling sites are shown in red. Dark colored areas are bare ice without snow due to strong wind. c Close-up of the rectangular area shown in (b). Sampling sites are shown in red. $\mathbf{d}$ Photograph of tephra-bearing ice layer exposed on ice surface around Site JARE54-ASH1 looking at the direction of Site JARE54-ASH2. Clear bluish ice on the left is the ice without volcanic ash

opened to confirm that ice block sample was not melting. The results were processed with the software OsiriX (http://www.osirix-viewer.com).
A small ice block sample was taken from each of the three sites and each ice block sample was melted in a small plastic tray, dried and gathered with a thin brush 
Table 1 List of sampling sites

\begin{tabular}{lllll}
\hline Sampling sites & Date & Latitude $\left(^{\circ}\right)$ & Longitude $\left(^{\circ}\right)$ & $\begin{array}{l}\text { Elevation } \\
(\mathbf{m})\end{array}$ \\
\hline JARE54-ASH1 & January 30, 2013 & $72^{\circ} 38^{\prime} 16.57^{\prime \prime} \mathrm{S}$ & $24^{\circ} 47^{\prime} 27.67^{\prime \prime} \mathrm{E}$ & 2819 \\
JARE54-ASH2 & January 30, 2013 & $72^{\circ} 38^{\prime} 45.97^{\prime \prime} \mathrm{S}$ & $24^{\circ} 48^{\prime} 50.00^{\prime \prime} \mathrm{E}$ & 2840 \\
JARE54-ASH3 & January 30, 2013 & $72^{\circ} 38^{\prime} 56.85^{\prime \prime} \mathrm{S}$ & $24^{\circ} 49^{\prime} 07.93^{\prime \prime} \mathrm{E}$ & 2993 \\
\hline
\end{tabular}

Table 2 List of ice block samples

\begin{tabular}{|c|c|c|c|c|}
\hline Sample_No & Ice (g) & Ash (mg) & $\begin{array}{l}\text { Ash content } \\
\text { (wt\%) }\end{array}$ & Comments \\
\hline JARE54-ASH1-1 & 3.879 & 1.8 & 0.046 & AGM \\
\hline JARE54-ASH2-1 & 5.312 & 0.3 & 0.006 & \\
\hline JARE54-ASH3-1 & 3.427 & 5.4 & 0.158 & AGM \\
\hline JARE54-ASH1-2 & 2.250 & 2.2 & 0.098 & $\begin{array}{c}\text { X-ray CT, SQUID } \\
\text { gradiometer }\end{array}$ \\
\hline JARE54-ASH2-2 & 2.850 & 0.2 & 0.007 & $\begin{array}{c}\text { X-ray CT, SQUID } \\
\text { gradiometer }\end{array}$ \\
\hline JARE54-ASH3-2 & 1.980 & 4.5 & 0.227 & $\begin{array}{c}\text { X-ray CT, SQUID } \\
\text { gradiometer }\end{array}$ \\
\hline JARE54-ASH1-3 & 4.207 & 7.1 & 0.169 & Curie balance \\
\hline JARE54-ASH2-3 & 13.070 & 0.6 & 0.005 & \\
\hline JARE54-ASH3-3 & 12.782 & 3.7 & 0.029 & Curie balance \\
\hline JARE54-ASH1-4 & 18.816 & 9 & 0.048 & Curie balance \\
\hline JARE54-ASH3-4 & 45.743 & 6.8 & 0.015 & Curie balance \\
\hline
\end{tabular}

onto chartulae. In order to increase the speed of drying, the top clear layer was discarded and replaced with ethanol after about an hour of settlement. Mainly due to the process of discarding, part of smaller particles (i.e., grain size of less than a few microns) may have possibly been lost. The size and number of particles extracted from JARE54-ASH2-1 was not enough, and the particles extracted only from JARE54-ASH1-1 and JARE54-ASH3-1 were used for further analysis. The particles turned out to be fresh glassy volcanic ash under a binocular microscope with diameters of $\sim 50 \mu \mathrm{m}$. The ash particles were mounted on a glass disk $(t=5 \mathrm{~mm}$, phi $=24 \mathrm{~mm}$ ) with an epoxy resin, polished and were analyzed with an electron probe microanalyzer (EPMA; JEOL JXA-8900) installed at GSJ. After microtextural observations using backscattered electron images (BEIs) using the EPMA, major element analysis ( $\mathrm{Si}, \mathrm{Ti}, \mathrm{Al}, \mathrm{Fe}$, $\mathrm{Mn}, \mathrm{Mg}, \mathrm{Ca}, \mathrm{Na}, \mathrm{K} \mathrm{S}, \mathrm{Cl}$ and $\mathrm{F}$ ) were performed with an accelerating voltage of $15 \mathrm{kV}$, probe current of $12 \mathrm{nA}$ and probe diameter of $4 \mu \mathrm{m}$, using a wavelength-dispersive X-ray spectroscopy (WDS) and the ZAF correction. The extracted particles were also analyzed with an alternating gradient field magnetometer (AGM) at GSJ to obtain magnetic hysteresis parameters and isothermal remanent magnetization (IRM) acquisition curves and to draw first-order reversal curve (FORC) diagrams. For FORC measurements, following parameters were used: $T_{\text {avg }}=0.4 \mathrm{~s}, H_{\mathrm{b}}=-20 \sim+20 \mathrm{mT}, H_{\mathrm{c}}=0-60 \mathrm{mT}$, $H_{\text {sat }}=1.4 \mathrm{~T}, N_{\text {curves }}=150$. Data were processed by the software FORCinel version 2.0 (Harrison and Feinberg 2008) using VARIFORC grid method (Egli 2013) with $s_{\mathrm{c}, 0}=7, s_{\mathrm{b}, 0}=3, s_{\mathrm{c}, 1}=s_{\mathrm{b}, 1}=6$, and $\lambda=0.1$. A magnetic balance (NMB-89, Natsuhara Giken, Osaka, Japan) at the CMCR, Kochi University, was used to measure Curie temperature of ash (4-5 mg) extracted from melted ice up to $700{ }^{\circ} \mathrm{C}$ in vacuum $(\sim 1-10 \mathrm{~Pa})$ with a field of $0.3 \mathrm{~T}$ at a rate of $10^{\circ} \mathrm{C} / \mathrm{min}$.

SQUID rock magnetometer (SRM-760; 2G Enterprises) was used to measure remanent magnetization of ice block samples. First, a block ice sample from each of the three sites was prepared and natural remanent magnetization (NRM) was measured by stepwise demagnetization with AC magnetic field of 0, 5, 10, 15, 20, 30, $40 \mathrm{mT}$. Second, anhysteretic remanent magnetization (ARM) was imparted in DC magnetic field of $50 \mathrm{mT}$ and AC magnetic field of $80 \mathrm{mT}$, then the samples were stepwise demagnetized with AC magnetic field of $0,5,10,15,20,30,40 \mathrm{mT}$.

A three-axis LTS-SQUID gradiometer at KIT was used to measure magnetic gradients in three axes just above tephra-bearing ice block samples and model samples. The gradiometer is based on $\mathrm{Nb} / \mathrm{AlAlOx} / \mathrm{Nb}$ Josephson junctions with a flux transformer (Jacox and Ketchen 1981), which was fabricated on a $5 \mathrm{~mm} \times 5 \mathrm{~mm}$ silicon chip using the similar thin-film processing described in Kawai et al. (2005). The gradiometric planar pickup coil, which is also integrated on the same chip, has the area of $1.5 \mathrm{~mm} \times 1.5 \mathrm{~mm}$ with the baseline of $3 \mathrm{~mm}$ (Fig. 2). The field resolution of the gradiometer is measured as $10 \mathrm{fT} / \sqrt{ } \mathrm{Hz} / \mathrm{mm}$. Measurements were conducted with $5 \mathrm{~mm}$ distance between surface of samples and a fiberreinforced plastic housing leaving $9 \mathrm{~mm}$ between upper surface of sample and plane of $z$ axis gradiometer coil. Model samples were measured in room temperature, whereas ice block samples were measured in a plastic tray which is placed above another tray filled with $\mathrm{LN}_{2}$ to keep the temperature of ice sample below ice freezing point (approximate temperature -100 to $-10^{\circ} \mathrm{C}$ depending on parts of ice blocks). The tray with samples was put 

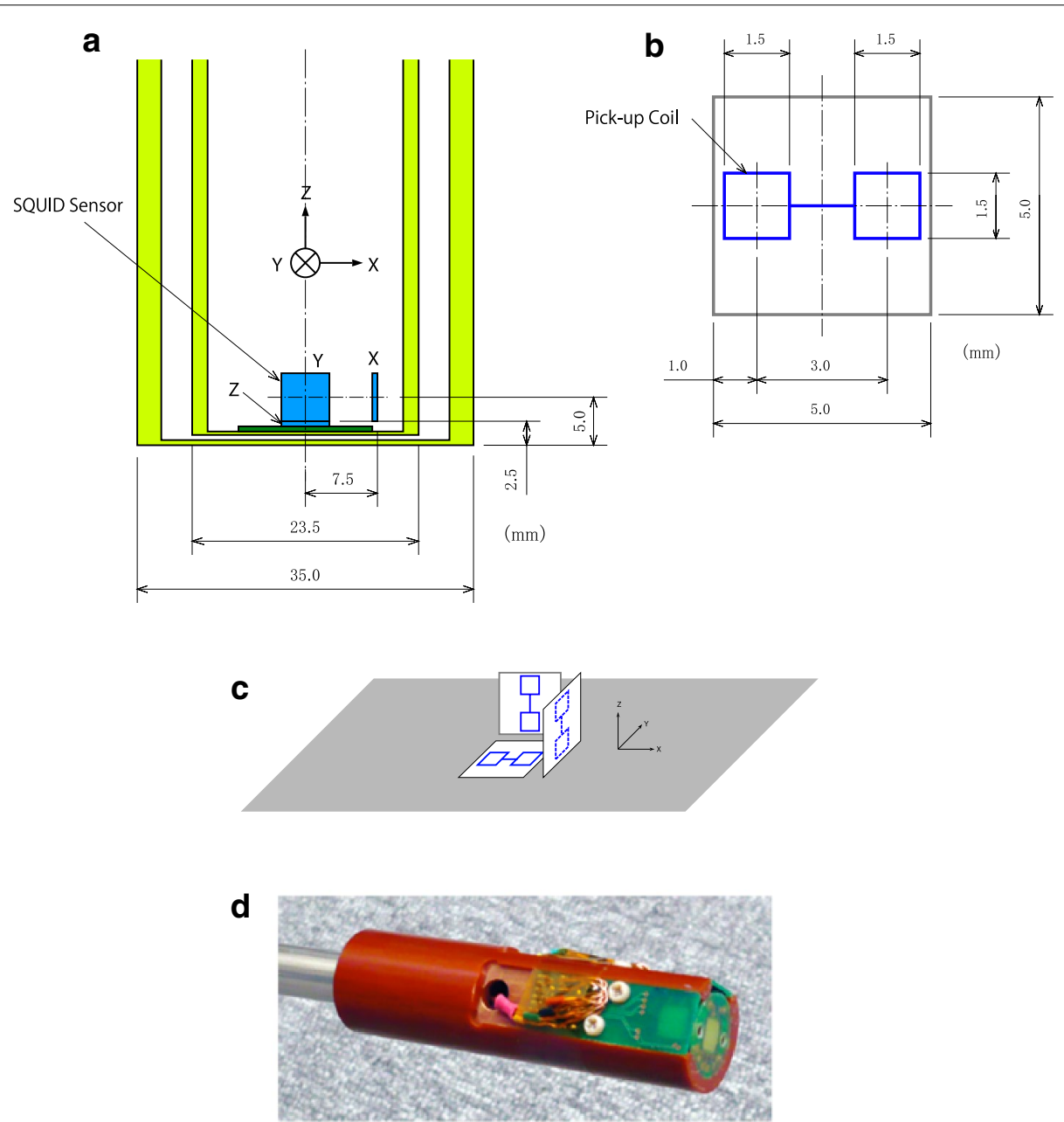

Fig. 2 Schematic figures of three axes SQUID gradiometer system. a Cross section of a cryostat with three axes SQUID sensors. b Close-up of a gradiometer pickup coil and a SQUID. c Geometry of three axes pickup coils. d Photograph of assembled pickup coils and SQUIDs

on a non-magnetic track and moved stepwise at intervals of $1 \mathrm{~mm}$. The signal from the gradiometer is obtained at a sampling rate of $200 \mathrm{~Hz}$ with low-pass filter (LPF) of $10 \mathrm{~Hz}$. Upon each stepwise movement of the tray, a trigger is produced and 80 data are acquired for each position. Twenty data points were averaged from the time when transient shift due to LPF has passed and used for further analysis. First, a block ice sample from each of the three sites was prepared and natural remanent magnetization (NRM) was measured. Second, IRM was imparted in 25-mT DC magnetic field for about $5 \mathrm{~s}$ on samples in the center of a Helmholtz-type static magnet with DC current.

\section{Results}

\section{Microfocus X-ray CT}

Similar to the previous study of microfocus X-ray CT scanning on ice block samples (Dadic et al. 2013), we could discriminate air bubbles, ice and solid particles based on CT value of each boxel. Figure $3 a-c$ shows the $3 \mathrm{D}$ perspective views of microfocus X-ray CT scan images showing distribution of particles with density higher than ice (red pixels; CT values higher than 15,200). Grayish pixels represent ice (with CT values lower than 13,875, 13,648 and 13,569 for ice 1, ice 2 and ice 3, respectively), and dark pixels are air bubbles. Ash contents for block samples JARE54-ASH1-2 and JARE54-ASH3-2 are 0.098 and 0.227 , respectively (Table 2). On the other hand, JARE54-ASH2-2 has much lower ash content. The difference in ash content could be recognized as difference in number of red pixels in Fig. 3a-c. Particles smaller than the pixel size $(30 \mu \mathrm{m} \times 30 \mu \mathrm{m} \times 30 \mu \mathrm{m})$ may not be well distinguished as pixels with $\mathrm{CT}$ values corresponding to the density of volcanic ash. Figure 3a, b shows scattered distribution of red pixels, whereas Fig. 3c shows rather clustered distribution of red pixels. There are no clear layered structures in the three images. The complete 3D 

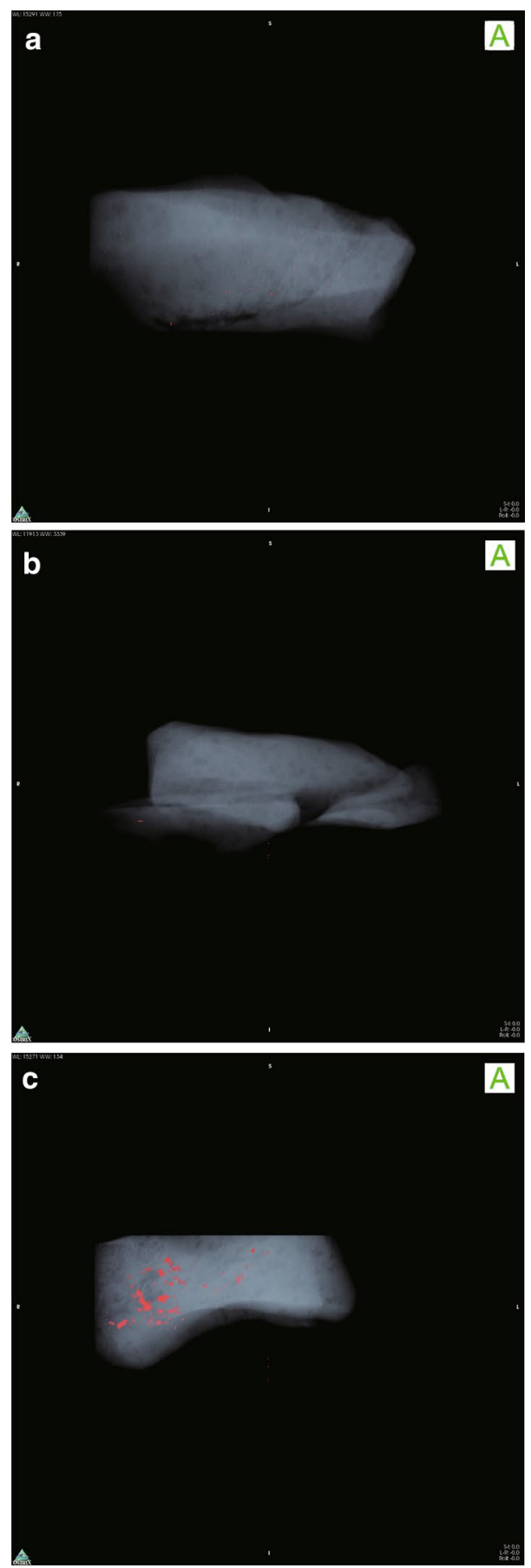

Fig. 3 3D perspective view of $\mathrm{X}$-ray CT scan of tephra-bearing ice block samples. a JARE54-ASH1, b JARE54-ASH2, c JARE54-ASH3.

Greenish pixels correspond to ice, and darker pixels are air bubbles. Red pixels are those with CT values higher than 15,200, which corresponds to particles with density higher than ice such as volcanic ash

distributions could be recognized as rotation movies in supplementary materials (Additional file 1, Additional file 2 , Additional file 3 ). The difference in distributions of red pixels could be controlled by particle density heterogeneity such as distance from the bottom of the tephrabearing ice layer as well as location of the sites.

\section{Geochemical analysis}

The BEIs revealed that the particles are volcanic ash and consist of vesiculated fresh glass and microphenocrysts. No clear difference was recognized between the samples JARE54-ASH1 (Fig. 4a) and JARE54-ASH3 (Fig. 4b), in terms of their grain size, grain shape, vesicularity, crystallinity, microtexture (size and shapes of minerals and vesicles), mineral assemblages, chemical composition of the mineral and matrix glass and their color under binocular microscope. Size of each volcanic particle was confirmed by averaging the lengths of major axis and minor axis of each grain in the electron microscope images. Typical individual volcanic particle $(\sim 50 \mu \mathrm{m})$ consists of multiple mineral grains such as plagioclase, pyroxene, magnetite (e.g., $10 \mu \mathrm{m}$ ) and volcanic glass. Major element analyses of volcanic glass by EPMA are summarized in Table 3 . Chemical composition of matrix glass belongs to a low-K basaltic andesite group, ranging from $\mathrm{SiO}_{2}$ 60-62 wt\% and $\mathrm{K}_{2} \mathrm{O} 0.40-0.50 \mathrm{wt} \%$ (Fig. 4c, solid circles). These are similar to the chemical composition of volcanic glass of Type B ash (open circle) analyzed by Naraoka et al. (1991) for a tephra-bearing ice layer in Nansen Ice Field located south of point A233 ( $\left.72^{\circ} 44^{\prime} 13^{\prime \prime} \mathrm{S}, 24^{\circ} 10^{\prime} 28^{\prime \prime} \mathrm{E}\right)$. In addition, these are similar to the chemical composition of volcanic glass of tephra layers in the EPICA-Dome C ice core with low-alkali tholeiitic signatures (gray circles), which are considered to originate from the South Sandwich Islands (Narcisi et al. 2005). Crystallinity of the ash particles is primarily $<40$ vol\%. The ash particle include microphenocrysts of plagioclase (core An 65-90 (mostly 65-77) and rim An 57-65, where An represents anorthosite content), orthopyroxene (En mostly 58-59, where En represents enstatite content), clinopyroxene (Wo mostly 23-37, where Wo represents wollastonite content) and Fe-Ti oxide mineral (XUsp mostly 0.2-0.35; Fig. 4d, where XUsp represents ulvospinel content).

\section{Rock magnetism}

Stepwise AF demagnetization of NRM for ice block samples shows that the intensity of magnetizations is $\sim 2 \times$ $10^{-7} \mathrm{~A} \mathrm{~m}^{2} / \mathrm{kg}$ for JARE54-ASH1-1 and $4 \times 10^{-7} \mathrm{~A} \mathrm{~m}^{2} /$ $\mathrm{kg}$ for JARE54-ASH3-1 (Fig. 5a). JARE54-ASH2-1 shows much weaker intensity of magnetization $\sim 1 \times 10^{-8} \mathrm{~A} \mathrm{~m}^{2}$ / $\mathrm{kg}$ close to the detection limit, which is consistent with the absence of visible ash particles in the ice sample. Figure 5b shows intensity of ARM measured on JARE54ASH1-1 (JARE54-ASH3-1) as $\sim 1 \times 10^{-6} \mathrm{~A} \mathrm{~m}^{2} / \mathrm{kg}$ $\left(\sim 1.8 \times 10^{-6} \mathrm{~A} \mathrm{~m}^{2} / \mathrm{kg}\right)$, respectively. ARM for JARE54ASH2-1 is weaker intensity of $\sim 6 \times 10^{-8} \mathrm{~A} \mathrm{~m}^{2} / \mathrm{kg}$. 
a
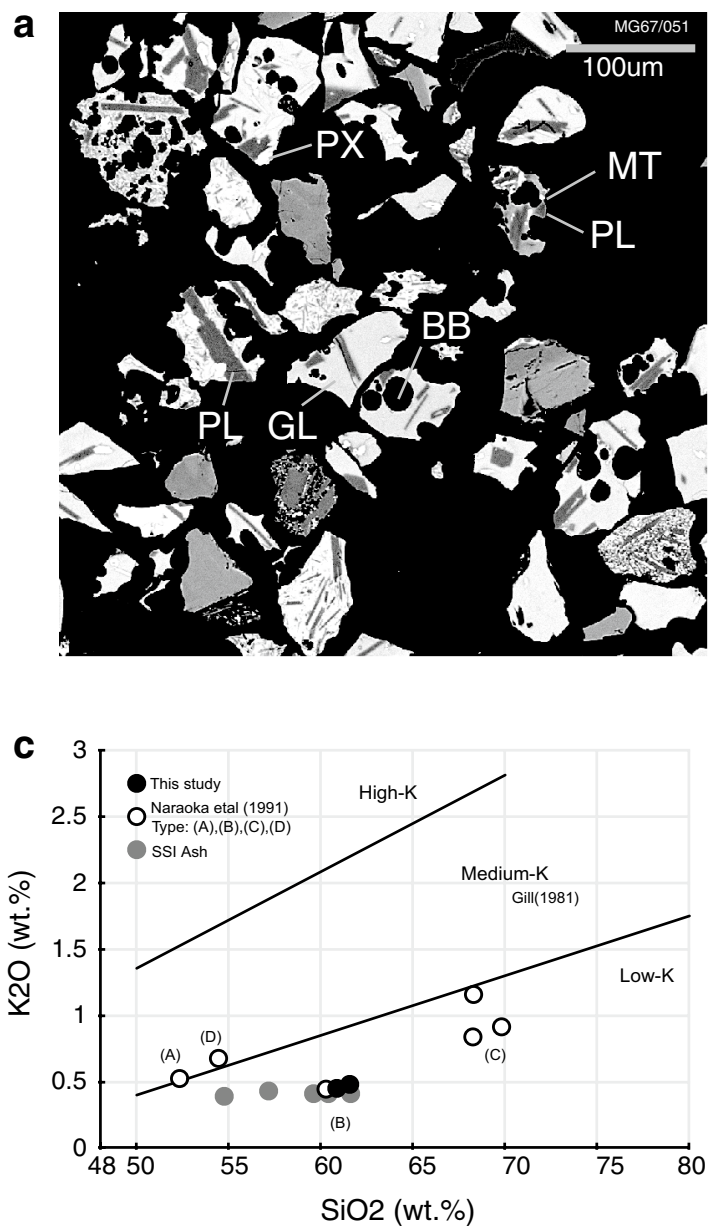

b

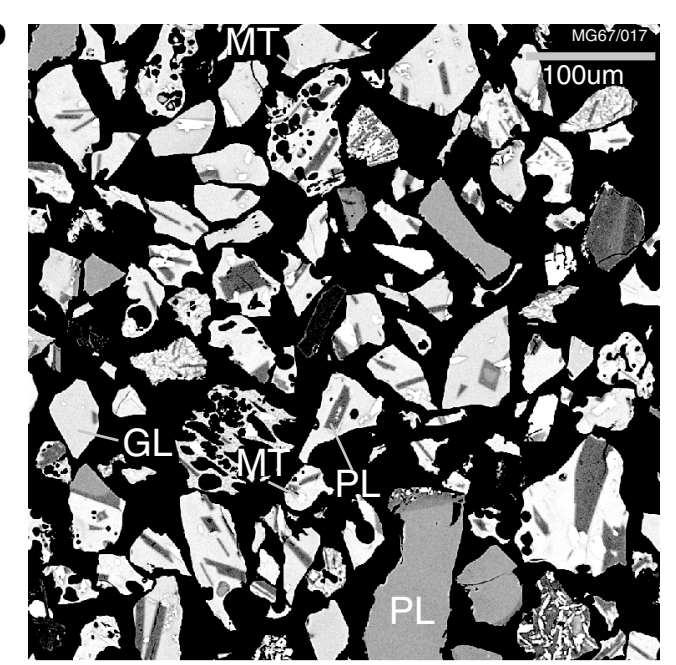

d

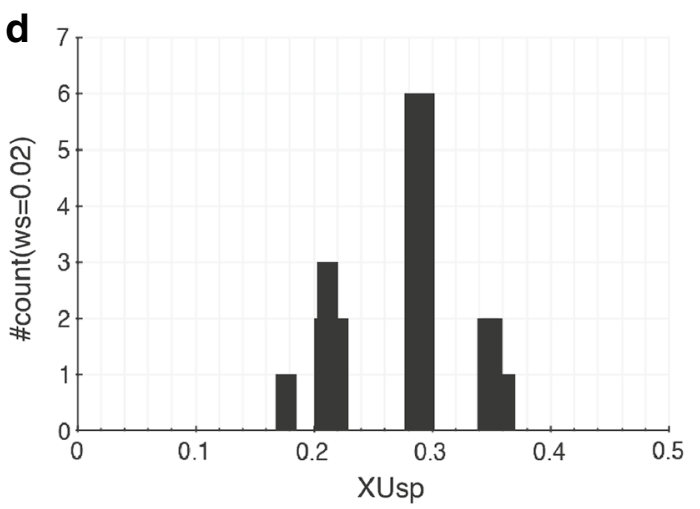

Fig. 4 Backscattered electron images (BEls) of volcanic ash particles extracted from tephra-bearing ice block samples collected from Sites a JARE54ASH1 and b JARE54-ASH3. BB bubble, GL glass, MT titanomagnetite, PL plagioclase, PX pyroxene. c Harker diagram of $\mathrm{K}_{2} \mathrm{O}$ for volcanic glass. Black solid circles are data from this study, white circles are data from Naraoka et al. (1991), and gray solid circles are from Narcisi et al. (2005). Boundary of low-K, medium-K and high-K is from Gill (1981). d Histogram of ulvospinel content for the analyzed titanomagnetite grains

Table 3 Major element compositions of volcanic glass analyzed with EPMA (Additional file 4, Additional file 5: Table S1)

\begin{tabular}{|c|c|c|c|c|c|c|c|c|c|c|c|c|c|}
\hline Sample & $\mathbf{N}$ & $\mathrm{SiO}_{2}$ & $\mathrm{TiO}_{2}$ & $\mathrm{Al}_{2} \mathrm{O}_{3}$ & $\mathrm{FeO}$ & $\mathrm{MnO}$ & $\mathrm{MgO}$ & $\mathrm{CaO}$ & $\mathrm{Na}_{2} \mathrm{O}$ & $\mathrm{K}_{2} \mathrm{O}$ & $\mathrm{SO}_{2}$ & $F$ & $\mathrm{Cl}$ \\
\hline \multicolumn{14}{|c|}{ JARE54-ASH1 } \\
\hline Mean & 14 & 61.56 & 1.05 & 13.76 & 10.50 & 0.20 & 2.46 & 6.85 & 2.99 & 0.48 & 0.11 & 0.01 & 0.15 \\
\hline $1 \sigma$ & & 1.56 & 0.12 & 0.53 & 0.77 & 0.02 & 0.38 & 0.38 & 0.16 & 0.07 & 0.07 & 0.01 & 0.05 \\
\hline \multicolumn{14}{|c|}{ JARE54-ASH3 } \\
\hline Mean & 42 & 60.86 & 1.07 & 14.01 & 10.64 & 0.20 & 2.56 & 7.08 & 2.98 & 0.45 & 0.08 & 0.01 & 0.15 \\
\hline $1 \sigma$ & & 0.61 & 0.07 & 0.73 & 0.61 & 0.04 & 0.25 & 0.26 & 0.23 & 0.03 & 0.03 & 0.02 & 0.02 \\
\hline \multicolumn{14}{|l|}{ Total } \\
\hline Mean & 56 & 61.04 & 1.06 & 13.95 & 10.61 & 0.20 & 2.53 & 7.02 & 2.99 & 0.45 & 0.09 & 0.01 & 0.15 \\
\hline $1 \sigma$ & & 0.98 & 0.08 & 0.69 & 0.65 & 0.04 & 0.29 & 0.31 & 0.21 & 0.05 & 0.04 & 0.02 & 0.03 \\
\hline
\end{tabular}

$N$ number of analyzed grains

Figure 5c shows IRM acquisition curves for JARE54ASH1-1 and JARE54-ASH3-1. The curves show that the magnetic minerals were mostly saturated at $\sim 300 \mathrm{mT}$.
Saturation magnetization per particle weight is higher for a sample taken from JARE54-ASH1 than from JARE54-ASH3. The derivative of the IRM acquisition 


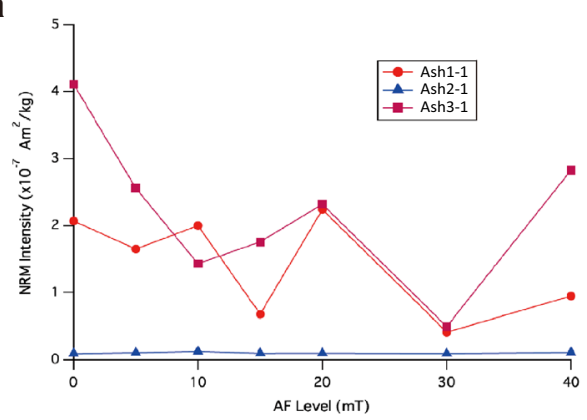

C
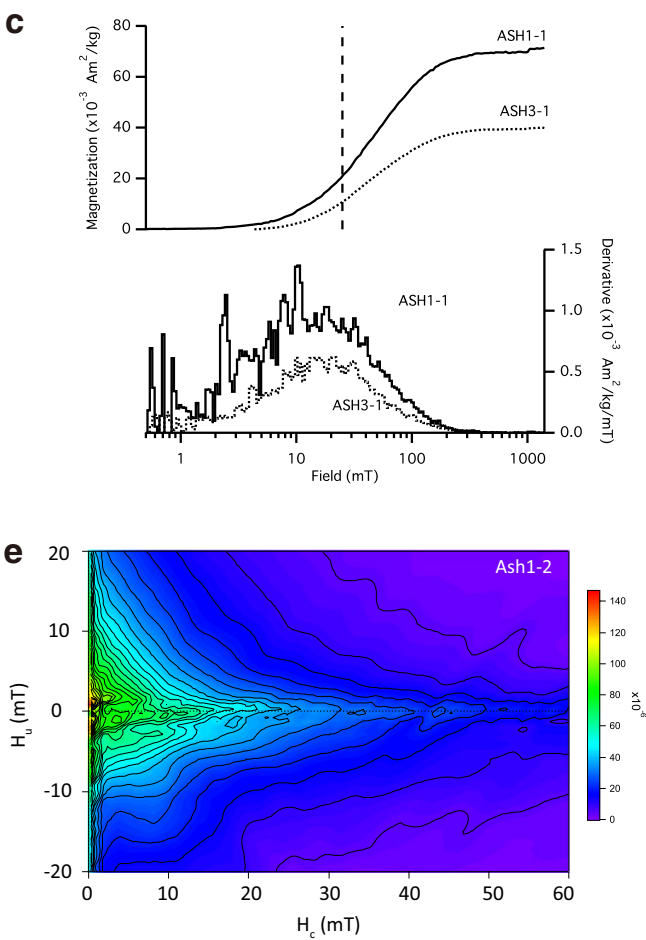

g

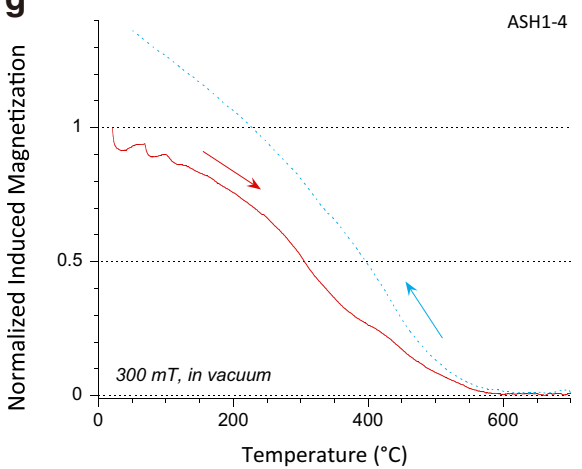

b

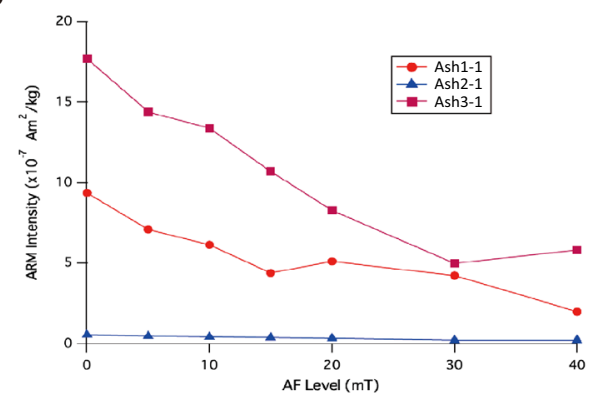

d

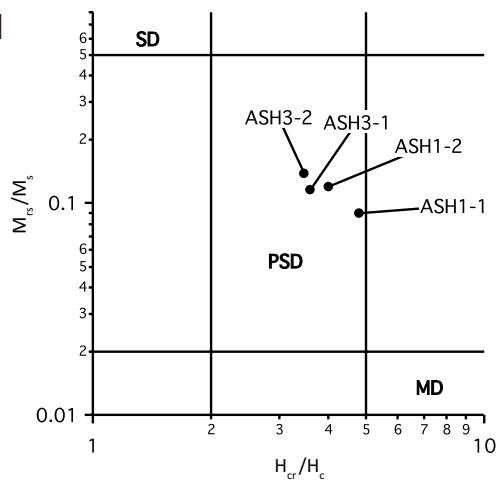

h

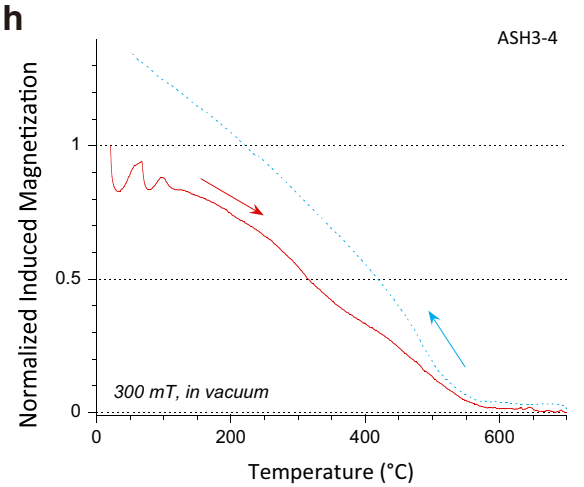

Fig. 5 Rock magnetic results of block ice samples and extracted grains. Stepwise AF demagnetization of a NRM and b ARM for JARE54-ASH1-1 (red circle), JARE54-ASH2-1 (blue triangle) and JARE54-ASH3-1 (green rectangle). c IRM acquisition curves (upper) for JARE54-ASH1-1 (solid curve) and JARE54-ASH3-1 (dotted curve). Vertical broken line represents DC magnetic field of $25 \mathrm{mT}$, which was used to magnetize ice samples for the measurements with LTS-SQUID gradiometer. Lower diagram is the derivative of IRM acquisition curves. $\mathbf{d}$ Hysteresis parameters were shown on Day plot (Day et al. 1977). ASH1-1 (ASH3-1) corresponds to JARE54-ASH1-1 (JARE54-ASH3-1). FORC diagrams are shown for e JARE54-ASH1-2 and $\mathbf{f} J$ ARE54ASH3-2, respectively. Heating (cooling) curves of Curie balance measurements are plotted as red (blue) curves for $\mathbf{g}$ JARE54-ASH1 and $\mathbf{h}$ JARE54ASH3. Note that some characteristic behaviors that appeared in the heating curves below approximately $150^{\circ} \mathrm{C}$ are artifact due to the instrument 
curves shows broad distribution of coercivities with a peak around $10 \mathrm{mT}$ for JARE54-ASH1-1 and $20 \mathrm{mT}$ for JARE54-ASH3-1. Vertical broken line represents $25 \mathrm{mT}$, which is used to acquire IRM for the measurements with the gradiometer. Magnetic hysteresis properties were measured on four sets of particles taken from two sites and plotted on Day plot (Fig. 5d). The volcanic particles included in tephra-bearing ice samples from Nansen Ice Field are distributed around pseudo-single-domain (PSD) and multi-domain (MD) particle size range. FORC diagrams were also measured on samples from the two sites (Fig. 5e, f). The results show several features including peaks close to the origin, broad peaks between 0 and $30 \mathrm{mT}$ with vertical spread, central ridges extending to the measured limit of $60 \mathrm{mT}$.

Thermomagnetic curves for JARE54-ASH1 and JARE54-ASH3 show Curie temperatures at 360-370 and $450-550^{\circ} \mathrm{C}$ in heating curves (red curves; Fig. $5 \mathrm{~g}$, h) and at $\sim 500{ }^{\circ} \mathrm{C}$ in cooling curves (blue curves). Cooling curves show an increase in magnetization after heating. Assuming that the magnetic mineral is titanomagnetite, the lower Curie temperature phase in heating curves corresponds to titanomagnetite of XUsp $\sim 0.34$ (Lattard et al. 2006). This is consistent with XUsp estimated from EPMA analysis. Existences of the higher Curie temperature phases may indicate the production of magnetite from titanomagnetite by heating in vacuum.

\section{Ice block measurement with three-axis LTS-SQUID}

Ice block samples of JARE54-ASH1-2, JARE54-ASH2-2 and JARE54-ASH3-2 were subjected to measurements of natural remanent magnetization (NRM) with the gradiometer while cooling with $\mathrm{LN}_{2}$ (Fig. 6). Although the mechanism is not clear, the blank tray with $\mathrm{LN}_{2}$ measured with the gradiometers showed a small amount of magnetic signal, especially in $Y$ axis. Thus, the blank tray with $\mathrm{LN}_{2}$ and drift of the measurements were corrected for all the diagrams. JARE54-ASH1-2 and JARE54-ASH3-2 show peaks in $Z$ axis gradiometer magnetic field intensity of 4-8 pT in $Z$ axis gradiometer. JARE54-ASH2-2 shows only a significant peak at $90 \mathrm{~mm}$, which might be a magnetic contamination away from the ice block sample. The average noise level for the measurements in $Z$ axis gradiometer is about $0.6 \mathrm{pT}$.

After the measurement of NRM, DC magnetic field of $25 \mathrm{mT}$ was put on these samples in the direction of $X$ axis and were subjected to measurements with the gradiometer (Fig. 7). All the ice block samples show peaks centered around zero position. JARE54-ASH1-2 and JARE54-ASH3-2 show relatively large peaks of about 400 and 1200 pT, whereas JARE54-ASH2-2 shows a small peak of about $10 \mathrm{pT}$. The average noise level for the measurements in $Z$ axis gradiometer is about $0.6 \mathrm{pT}$, which is the same as the measurements for NRM. As a result, signal-to-noise ratio was improved thanks to the enhancement of signal by artificial magnetization.

\section{Half-cylinder theoretical response and model sample with Antarctic ash}

Figure 8a shows the top view of $z$ axis coil geometry together with assumed thin volcanic ash layer. Theoretical response curves for the gradiometers were calculated for half-cylinder with radius of $29 \mathrm{~mm}$ and variable thicknesses with uniform magnetization in $X$ axis. Total magnetic moment for each thin slice is assumed to be the same value of $1.3 \times 10^{-9} \mathrm{~A} \mathrm{~m}^{2}$, which means dilution of the same amount of magnetic material with increasing total volume. The distance between the surface of half-cylinder sample and $z$ axis pickup coil was set to be $9 \mathrm{~mm}$. Theoretical curves for the gradiometer were calculated by using magnetic field values in the center of the two $1.5 \mathrm{~mm} \times 1.5 \mathrm{~mm}$ rectangular coils by integrating point source responses over the whole volume of each half-cylinder thin slice. Calculated theoretical responses of $Z$ axis gradiometer are plotted versus position for various thicknesses (Fig. 8b; right axis). Peak value decreases and half-width increases with increasing thickness of half-cylinder. Theoretical response for a point source with the same magnetization is also shown by broken line (Fig. 8b; left axis), which has much higher peak value and sharp response compared with the thin slices.

Figure 8c shows response in $X$ (black curve), $Y$ (red curve) and $Z$ axis (blue curve) gradiometers for thin model sample with volcanic ash particles of JARE54ASH3 mixed with epoxy glue. The block ice sample was melted, and the extracted particles were mixed with epoxy glue to make a half-cylinder model sample with $29 \mathrm{~mm}$ radius and $1 \mathrm{~mm}$ thickness. The sample was magnetized in $X$ axis with a DC magnetic field of $25 \mathrm{mT}$. Among three axes, $Z$ axis response has a highest peak of $152 \mathrm{pT}$, whereas $X$ axis response has a negative peak of $-85 \mathrm{pT}$. $Y$ axis response is nearly zero for the whole length, which is predicted from the theoretical calculation. $Z$ axis response could be well compared with the theoretical response with a thickness of $1 \mathrm{~mm}$. The distances of two zero crossings are $16 \mathrm{~mm}$ for both measured and theoretical responses. Negative lobes for theoretical response are $19 \%$ of the peak value on both sides, whereas those for measured response are 22 and $17 \%$ with asymmetry. The asymmetry might be caused by slight tilt of half-cylinder model slice relative to the axes of the gradiometer pickup coil. 

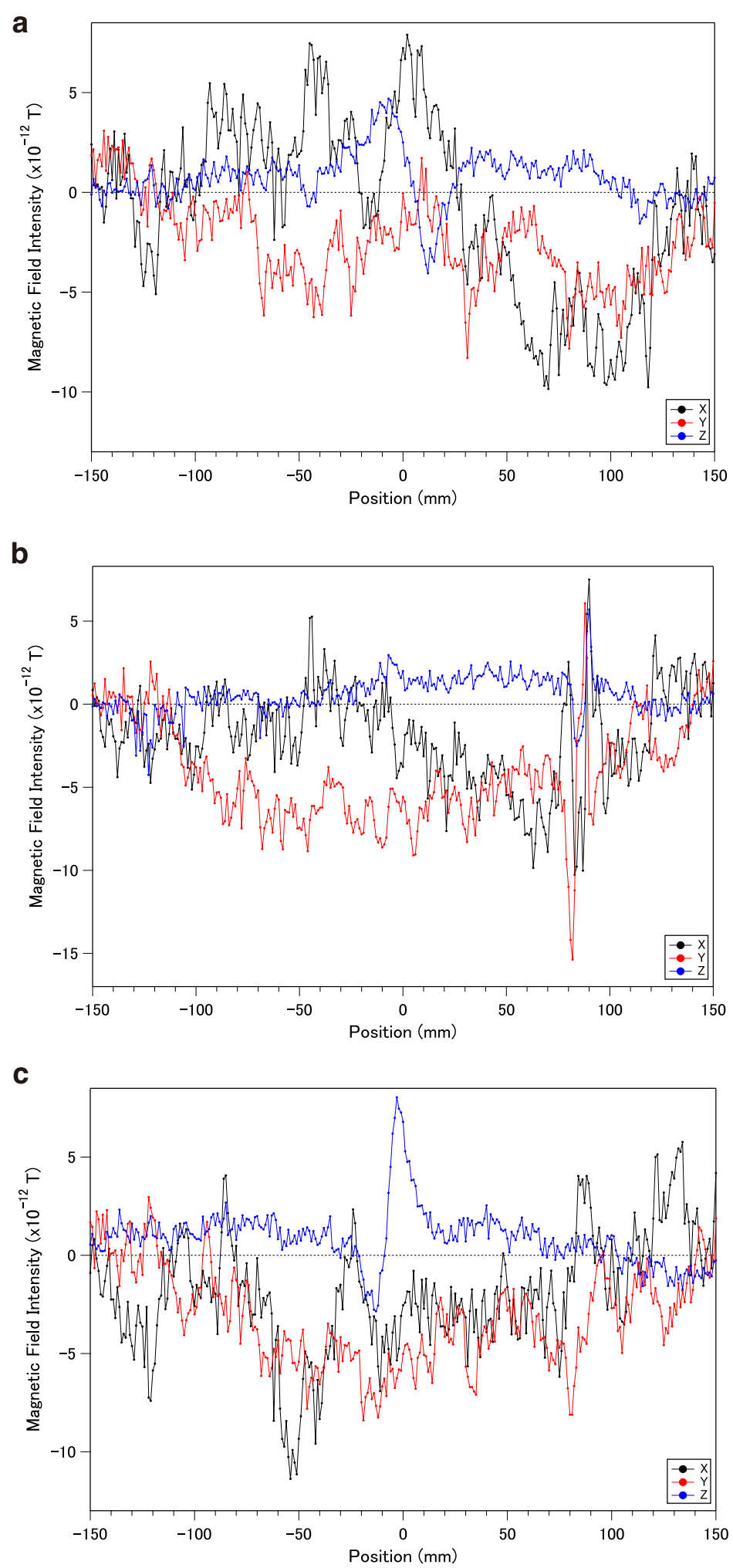

Fig. 6 Measurements of ice block samples in natural state using SQUID gradiometer for a JARE54-ASH1-2, b JARE54-ASH2-2 and c JARE54-ASH3-2. Black, red and blue symbols are magnetic field intensities in $X, Y$ and $Z$ axis, respectively. Each ice block sample is placed at zero position. Signal of blank tray filled with $\mathrm{LN}_{2}$ was subtracted 

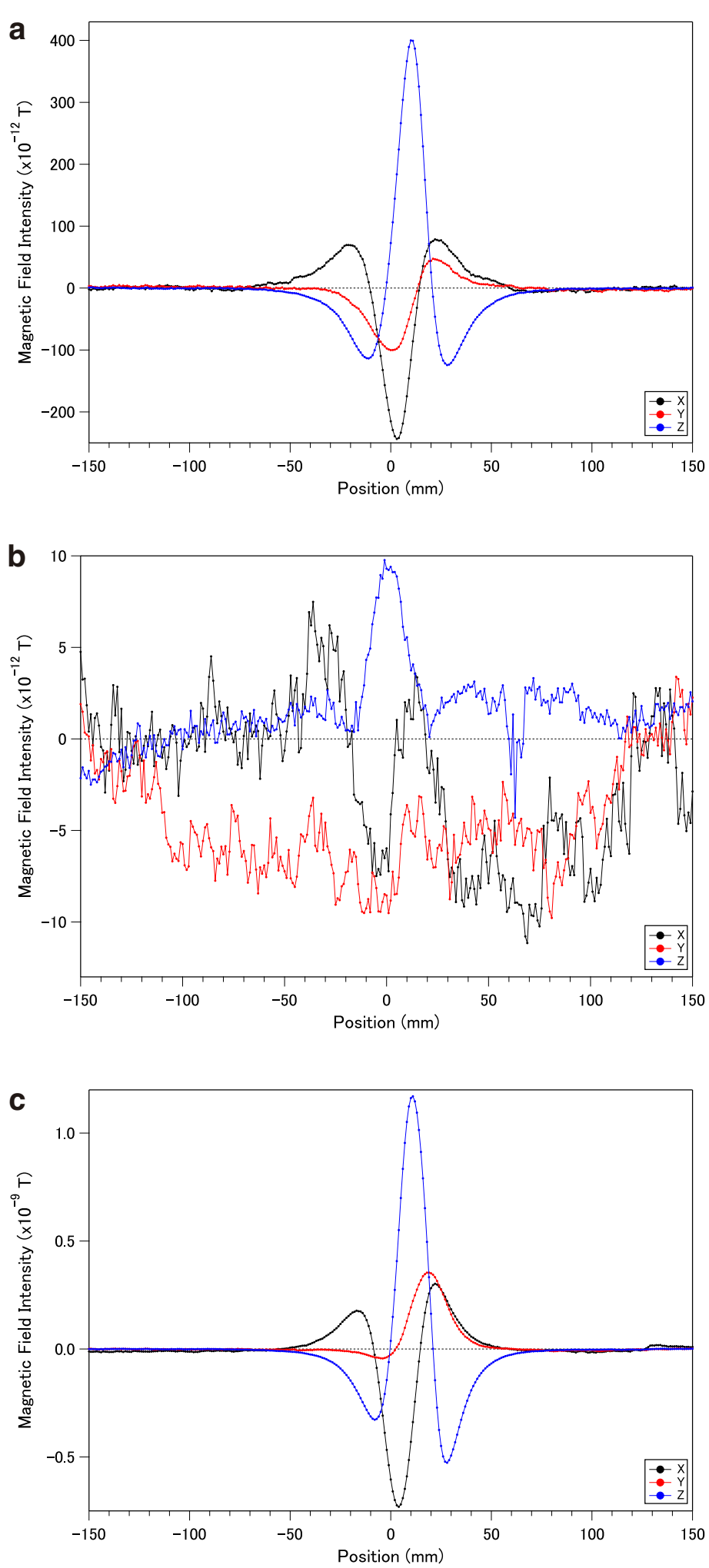

Fig. 7 Measurements of ice block samples with IRM using SQUID gradiometer for a JARE54-ASH1-2, b JARE54-ASH2-2 and c JARE54-ASH3-2. Black, red and blue symbols are magnetic field intensities in $X, Y$ and $Z$ axis, respectively. Each ice block sample is placed at zero position. Signal of blank tray filled with $\mathrm{LN}_{2}$ was subtracted 
a
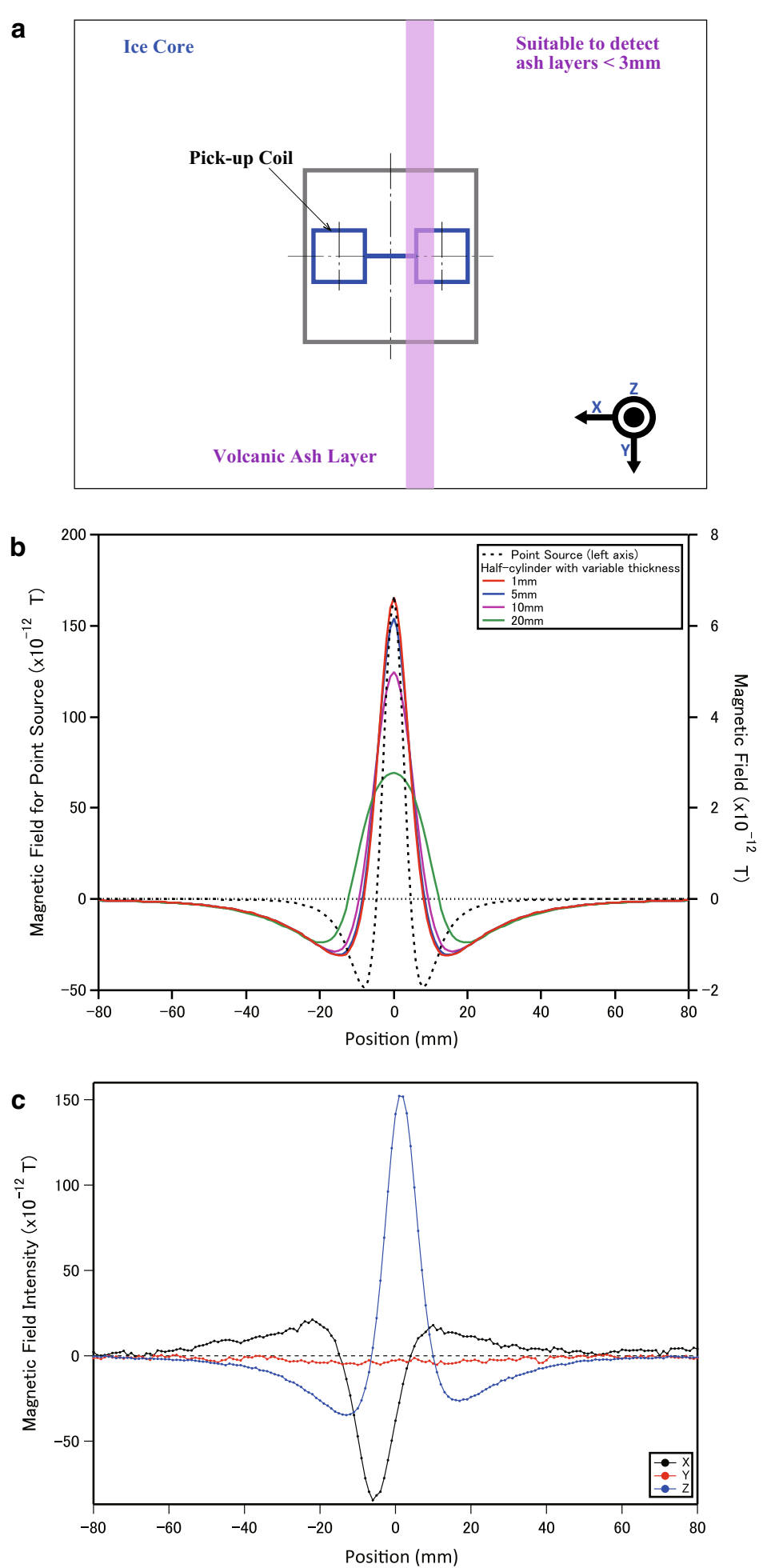

Fig. 8 a Schematic diagram showing the geometry and axes of gradiometer pickup coil, and model thin ash layer for a half-cylinder core. b Theoretical responses of $Z$ axis gradiometer (right axis) are plotted for half-cylinder (radius $29 \mathrm{~mm}$ ) model ash layer uniformly magnetized in $X$ axis with various thicknesses $\left(1,5,10\right.$ and $20 \mathrm{~mm}$ ). Total magnetic moment value for all the cases is $4.2 \times 10^{-9} \mathrm{~A} \mathrm{~m}^{2}$. Broken line (left axis) is response of a point source along centerline with the same magnetization at a distance of $9 \mathrm{~mm}$. c Response of thin model sample with $9 \mathrm{mg}$ volcanic ash particles of JARE54-ASH3 mixed with $220 \mathrm{mg}$ of epoxy glue in X (black curve), $Y$ (red curve) and Z axis (blue curve) gradiometers. The sample was magnetized in $X$ axis with a DC magnetic field of $25 \mathrm{mT}$ 


\section{Discussions}

\section{Origin of volcanic ash in tephra-bearing ice block}

Particles extracted from ice block samples collected in Nansen Ice Field were analyzed and found to be volcanic ash with chemical composition similar to Type B ash (low-K) reported by Naraoka et al. (1991) and group (a) ash of basaltic andesitic or andesitic compositions with affinity $\left(\mathrm{K}_{2} \mathrm{O}\right.$ ca. $\left.0.4 \mathrm{wt} \%\right)$ (Narcisi et al. 2005). They implied that Type B or group (a) ash might have been originated from the South Sandwich Islands, which is $2800 \mathrm{~km}$ away to the northwest from the sampling sites of this study (Fig. 1). Continuous distribution of tephrabearing ice layer with minimum extension from JARE54ASH1 to JARE54-ASH3 without significant grain size change may suggest relatively large volcanic eruption. The volcanic ash particles consist mainly of fresh blocky andesitic glass with small spherical bubbles (Fig. 4a, b), indicating explosive phreatomagmatic or magmatic eruption. Clusters of volcanic particles observed for X-ray CT image of JARE54-ASH3 may suggest the process of initial deposition onto surface of snow. Although age of eruption and deposition of volcanic ash is not clear, the tephra-bearing ice layer with volcanic ash should have been transported as the ice sheet moves and uplifted as the bare ice area is eroded by strong wind through significant time after deposition and consolidation.

Nishio et al. (1985) reported tephra-bearing layers on the bare ice surface in the Meteorite Ice Field near the Yamato Mountains, Dronning Maud Land, southwest of Syowa Station (Fig. 1). The volcanic glass shards were extracted from bare ice samples collected from the Ice Field, and the analyzed average chemical compositions $\left(N=14, \mathrm{SiO}_{2}: 57.92 \pm 0.71 \%, \mathrm{~K}_{2} \mathrm{O}: 0.39 \pm 0.06 \%\right)$ lie on the trend of this study (Fig. 4). This implies that the volcanic ash analyzed in this study and those reported by Nishio et al. (1985) may have been originated from the same area. Based on the chemical compositions, they suggested that the volcanic ash of the Ice Field near the Yamato Mountains might have been derived from a volcano of the South Sandwich Islands, which are about $3000 \mathrm{~km}$ away from the Yamato Mountains. They also mentioned about the median grain size of the analyzed particles $(40-55 \mu \mathrm{m})$ as a supporting evidence for the above-mentioned hypothesis.

East Antarctic deep ice cores (Dome Fuji, Vostok and EPICA-Dome C) are dominated by tephra events from volcanoes in the South Atlantic region (Narcisi et al. 2010). In particular, the South Sandwich Islands represent an important source for volcanic ash in East Antarctic ice. Relative abundance of ash layers from South Sandwich Islands decreases with increasing distance from the source (i.e., from Dome Fuji, through Vostok, to EPICA-Dome C). Seventeen out of twenty-three visible ash layers found in Dome Fuji ice core are considered to be originated from the South Sandwich Islands (Narcisi et al. 2010). Tephra layers in these ice cores from the volcanic province are also characterized by coarser volcanic ash grains than that for layers from other sources. The peak grain size of the tephra from South Sandwich Islands in EPICA-Dome C is $10 \mu \mathrm{m}$ (Narcisi et al. 2010). Maximum size of the volcanic ash grains found in Dome Fuji ice core is mostly $<50 \mu \mathrm{m}$ (Kohno et al. 2004).

Considering the location of our sampling sites between the South Sandwich Islands and Dome Fuji, coarser grains with size of $50 \mu \mathrm{m}$ could have been transported from the South Sandwich Islands to the studied area. This is also consistent with the fact that products from the South Sandwich Islands are characterized by very low $\mathrm{K}$ contents (Leat et al. 2003). Although the grain size of $50 \mu \mathrm{m}$ transported $2800 \mathrm{~km}$ away from the expected source area is relatively large, stronger westerly jet stream in the upper troposphere and lower stratosphere for the circum Antarctic regions could potentially transport the particles. Based on composite satellite data, Lazzara et al. (2014) calculated mean wind speed of high-latitude southern hemisphere above $\sim 7 \mathrm{~km}$ as $\sim 28 \mathrm{~m} / \mathrm{s}$ (i.e., $\sim 100 \mathrm{~km} / \mathrm{h}$ ). On the other hand, Suzuki (1983) estimated terminal fall velocities of volcanic particles as a function of mean diameter in the atmosphere. Terminal fall velocity of particles with mean diameter of $50 \mu \mathrm{m}$ is calculated as $\sim 0.1 \mathrm{~m} / \mathrm{s}$. Height of the volcanic cloud is controlled by the magma discharge rate and wind conditions (e.g., Suzuki and Koyaguchi 2013), which could reach up to $16 \mathrm{~km}$ (e.g., Prata et al. 2015). Assuming that volcanic cloud with column height of $12 \mathrm{~km}$ was formed by an explosive phreatomagmatic or magmatic eruption, ash particles with diameter of $50 \mu \mathrm{m}$ would have taken $\sim 28 \mathrm{~h}$ to settle down onto the surface of sampling sites (altitude $\sim 2 \mathrm{~km}$ ). The wind speed of westerly jet steam in Antarctic region $(\sim 100 \mathrm{~km} / \mathrm{h})$ is just enough for the particles to be transported from the South Sandwich Islands to the sampling sites with a distance of $2800 \mathrm{~km}$.

In order to confirm the correlations between tephras reported in this study and those from other areas in Antarctica, we have calculated the Euclidean distance function, $D$, for element concentrations in volcanic glass normalized by standard deviations (Perkins et al. 1995). Dunber and Kurbatov (2011) applied the distance function with 6 elements (i.e., $\mathrm{Fe}, \mathrm{Ca}, \mathrm{Ti}, \mathrm{Mg}, \mathrm{Mn}$ and $\mathrm{K}$ ) for Antarctic ice samples, which are also used for the tephras reported in this study. They also suggested that identical tephras typically have $D$ values around 4 and that $D$ values below 10 are considered as high degree of similarity. $D$ value between JARE-ASH1 and JARE-ASH3 (Table 3) is calculated as 1.0, which is consistent with the idea that these are identical. Thus, total average and standard 
deviation for elements in Table 3 were used for further analyses with other tephras in Antarctica reported previously (Table 4 ). $D$ value with Type B ash reported by Naraoka et al. (1991) is 2.9 and that with ash near the Yamato Mountains reported by Nishio et al. (1985) is 1.9 , suggesting that these could be identical to the tephra reported in this study or the source is the same. Group (a) tephra layers of EPICA-Dome C (Narcisi et al. 2005) with low $\mathrm{K}$ associated with South Sandwich Islands (132.6, 339.5, 923.8, 1804.0 and $2086.6 \mathrm{~m}$ ) gave smaller $D$ values $(2.5,3.2,1.0,8.6$ and 4.2$)$ suggesting the same origin. Volcanic ash layers in Vostok ice cores (Palais et al. 1987, 1989; Basile et al. 2001) with low K $(100,369,550$, 104, 547, 1280 Type A, 1992, 2169, 2231, 2260, 2326 and $2502 \mathrm{~m}$ ) show $D$ values lower than $10(3.4,1.8,9.0,2.5$, 7.1, 4.0, 10.3, 8.1, 4.9, 5.3, 4.2 and 4.6). Kohno et al. (2004) made correlation of tephra layers found in Dome Fuji ice core with those in Vostok based on major and trace elements (Table 4; numbers in the 'Correlation' column). Tephra layers in Dome Fuji correlated with the tephra layers in Vostok associated with South Sandwich Islands (505, 2026 and $2117 \mathrm{~m}$ ) show $D$ values lower than 10 (9.6, 5.3 and 1.9). Whole analyses of $D$ values suggest that the tephra layer investigated in this study could be correlated with the tephra layers distributed over a large area in Antarctica which is associated with South Sandwich Islands.

\section{Rock magnetic granulometry of volcanic ash}

FORC diagrams provide valuable information on the mixture of magnetic minerals with various domain states in natural sample. Thanks to the ability of VARIFORC to extract important features from FORC datasets, a mixture of magnetic minerals in various domain states could be resolved in FORC diagrams (Fig. 5e, f). Here we diagnose each feature based on the description summarized by Roberts et al. (2014). Sharp central ridges could be identified along horizontal lines at $H_{\mathrm{u}}=0$ extending from $\sim 15 \mathrm{mT}$ to the maximum $H_{\mathrm{c}}$ of $60 \mathrm{mT}$ and further, which is indicative of non-interacting single-domain (titano)magnetite. Strong peaks centered around the origin suggest the presence of particles near the SP to stable SD threshold size. Distributions along vertical lines at $H_{\mathrm{c}}=0$ could be created by the presence of SP particles. Triangular-shaped vertically spread broad peaks around 0-30 mT might be characteristics of PSD grains. This is also supported by the presence of troughs near the $H_{\mathrm{u}}$ axis in the negative region (lower half).

Although there might also be some amount of MD particles, contribution to the hysteresis parameters and FORC diagrams might be small and could not be resolved clearly. Titanomagnetite grains in PSD size could actually be identified in the electron microscopic images typically attached to the other mineral grains such as plagioclase (e.g., Fig. 4a, b). SP and SD size (titano)magnetite grains could exist as
Table $4 D$ value for a tephra layer reported in this study with tephras in Antarctica

\begin{tabular}{|c|c|c|c|c|}
\hline References & Area/ice core & $\begin{array}{l}\text { Sample/ } \\
\text { depth (m) }\end{array}$ & Correlation & $D$ value \\
\hline $\begin{array}{l}\text { Naraoka et al. } \\
\text { (1991) }\end{array}$ & $\begin{array}{l}\text { Nansen Ice } \\
\text { Field }\end{array}$ & $\begin{array}{l}\text { Type A } \\
88101908\end{array}$ & & 12.1 \\
\hline $\begin{array}{l}\text { Naraoka et al. } \\
\text { (1991) }\end{array}$ & $\begin{array}{l}\text { Nansen Ice } \\
\text { Field }\end{array}$ & $\begin{array}{l}\text { Type B } \\
88022501\end{array}$ & & 2.9 \\
\hline $\begin{array}{l}\text { Naraoka et al. } \\
\text { (1991) }\end{array}$ & $\begin{array}{l}\text { Nansen Ice } \\
\text { Field }\end{array}$ & $\begin{array}{l}\text { Type C } \\
88120503\end{array}$ & & 10.7 \\
\hline $\begin{array}{l}\text { Naraoka et al. } \\
\text { (1991) }\end{array}$ & $\begin{array}{l}\text { Nansen Ice } \\
\text { Field }\end{array}$ & $\begin{array}{l}\text { Type C } \\
88121105\end{array}$ & & 14.2 \\
\hline $\begin{array}{l}\text { Naraoka et al. } \\
\text { (1991) }\end{array}$ & $\begin{array}{l}\text { Nansen Ice } \\
\text { Field }\end{array}$ & $\begin{array}{l}\text { Type C } \\
89010201\end{array}$ & & 12.9 \\
\hline $\begin{array}{l}\text { Naraoka et al. } \\
\text { (1991) }\end{array}$ & $\begin{array}{l}\text { Nansen Ice } \\
\text { Field }\end{array}$ & $\begin{array}{l}\text { Type C } \\
88120402\end{array}$ & & 11.6 \\
\hline $\begin{array}{l}\text { Nishio et al. } \\
\text { (1985) }\end{array}$ & Allan Hills & Allan ash & & 46.3 \\
\hline $\begin{array}{l}\text { Nishio et al. } \\
\text { (1985) }\end{array}$ & $\begin{array}{l}\text { Yamato } \\
\text { Mountains }\end{array}$ & Yamato ash & & 1.9 \\
\hline $\begin{array}{l}\text { Kohno et al. } \\
\text { (2004) }\end{array}$ & Dome Fuji & 505 & 1 & 9.6 \\
\hline $\begin{array}{l}\text { Kohno et al. } \\
(2004)\end{array}$ & Dome Fuji & 1129 & 2 & 12.5 \\
\hline $\begin{array}{l}\text { Kohno et al. } \\
(2004)\end{array}$ & Dome Fuji & 1361 & & 63.5 \\
\hline $\begin{array}{l}\text { Kohno et al. } \\
\text { (2004) }\end{array}$ & Dome Fuji & 1849 & 3 & 49.7 \\
\hline $\begin{array}{l}\text { Kohno et al. } \\
\text { (2004) }\end{array}$ & Dome Fuji & 2026 & 4 & 5.3 \\
\hline $\begin{array}{l}\text { Kohno et al. } \\
\text { (2004) }\end{array}$ & Dome Fuji & 2117 & 5 & 1.9 \\
\hline $\begin{array}{l}\text { Kohno et al. } \\
(2004)\end{array}$ & Dome Fuji & 2170 & 6 & 8.3 \\
\hline $\begin{array}{l}\text { Narcisi et al. } \\
\text { (2005) }\end{array}$ & EPICA-Dome C & 132.6 & & 2.5 \\
\hline $\begin{array}{l}\text { Narcisi et al. } \\
(2005)\end{array}$ & EPICA-Dome C & 339.5 & & 3.2 \\
\hline $\begin{array}{l}\text { Narcisi et al. } \\
\text { (2005) }\end{array}$ & EPICA-Dome C & 434.7 & & 67.5 \\
\hline $\begin{array}{l}\text { Narcisi et al. } \\
\text { (2005) }\end{array}$ & EPICA-Dome C & 572 & & 13.5 \\
\hline $\begin{array}{l}\text { Narcisi et al. } \\
(2005)\end{array}$ & EPICA-Dome C & 923.8 & & 1.0 \\
\hline $\begin{array}{l}\text { Narcisi et al. } \\
\text { (2005) }\end{array}$ & EPICA-Dome C & 1117.1 & & 22.6 \\
\hline $\begin{array}{l}\text { Narcisi et al. } \\
\text { (2005) }\end{array}$ & EPICA-Dome C & 1265.1 & & 67.8 \\
\hline $\begin{array}{l}\text { Narcisi et al. } \\
\text { (2005) }\end{array}$ & EPICA-Dome C & 1732.5 & & 73.6 \\
\hline $\begin{array}{l}\text { Narcisi et al. } \\
(2005)\end{array}$ & EPICA-Dome C & 1796.3 & & 58.4 \\
\hline $\begin{array}{l}\text { Narcisi et al. } \\
\text { (2005) }\end{array}$ & EPICA-Dome C & 1804 & & 8.6 \\
\hline $\begin{array}{l}\text { Narcisi et al. } \\
\text { (2005) }\end{array}$ & EPICA-Dome C & 1868.3 & & 25.5 \\
\hline $\begin{array}{l}\text { Narcisi et al. } \\
\quad(2005)\end{array}$ & EPICA-Dome C & 2086.6 & & 4.2 \\
\hline
\end{tabular}


Table 4 continued

\begin{tabular}{|c|c|c|c|c|}
\hline References & Area/ice core & $\begin{array}{l}\text { Sample/ } \\
\text { depth }(m)\end{array}$ & Correlation & $D$ value \\
\hline $\begin{array}{l}\text { Narcisi et al. } \\
\text { (2005) }\end{array}$ & EPICA-Dome C & 2150.9 & & 9.7 \\
\hline $\begin{array}{c}\text { Palais et al. } \\
\text { (1987) }\end{array}$ & Vostok & 100 & & 3.4 \\
\hline $\begin{array}{l}\text { Palais et al. } \\
\text { (1989) }\end{array}$ & Vostok & 369 & 1 & 1.8 \\
\hline $\begin{array}{c}\text { Palais et al. } \\
\text { (1989) }\end{array}$ & Vostok & 550 & & 9.0 \\
\hline $\begin{array}{l}\text { Palais et al. } \\
\text { (1989) }\end{array}$ & Vostok & 641 & & 29.3 \\
\hline $\begin{array}{c}\text { Palais et al. } \\
\text { (1989) }\end{array}$ & Vostok & 1510 & & 49.8 \\
\hline $\begin{array}{l}\text { Basile et al. } \\
\text { (2001) }\end{array}$ & Vostok & 104 & & 2.5 \\
\hline $\begin{array}{l}\text { Basile et al. } \\
\text { (2001) }\end{array}$ & Vostok & 181 & & 10.8 \\
\hline $\begin{array}{l}\text { Basile et al. } \\
\text { (2001) }\end{array}$ & Vostok & 547 & & 7.1 \\
\hline $\begin{array}{l}\text { Basile et al. } \\
\text { (2001) }\end{array}$ & Vostok & 989 & 2 & 13.0 \\
\hline $\begin{array}{l}\text { Basile et al. } \\
\quad(2001)\end{array}$ & Vostok & 1280, Type A & & 4.0 \\
\hline $\begin{array}{l}\text { Basile et al. } \\
\text { (2001) }\end{array}$ & Vostok & 1280, Type B & & 64.6 \\
\hline $\begin{array}{l}\text { Basile et al. } \\
\text { (2001) }\end{array}$ & Vostok & 1431 & & 69.2 \\
\hline $\begin{array}{l}\text { Basile et al. } \\
\text { (2001) }\end{array}$ & Vostok & 1981 & & 7.5 \\
\hline $\begin{array}{l}\text { Basile et al. } \\
\text { (2001) }\end{array}$ & Vostok & 1992 & & 10.3 \\
\hline $\begin{array}{l}\text { Basile et al. } \\
\text { (2001) }\end{array}$ & Vostok & 1996 & & 74.6 \\
\hline $\begin{array}{l}\text { Basile et al. } \\
(2001)\end{array}$ & Vostok & 2169 & & 8.1 \\
\hline $\begin{array}{l}\text { Basile et al. } \\
\text { (2001) }\end{array}$ & Vostok & 2231 & & 4.9 \\
\hline $\begin{array}{c}\text { Basile et al. } \\
\text { (2001) }\end{array}$ & Vostok & 2260 & & 5.3 \\
\hline $\begin{array}{l}\text { Basile et al. } \\
\text { (2001) }\end{array}$ & Vostok & 2326 & & 4.2 \\
\hline $\begin{array}{l}\text { Basile et al. } \\
\text { (2001) }\end{array}$ & Vostok & 2502 & & 4.6 \\
\hline $\begin{array}{l}\text { Basile et al. } \\
(2001)\end{array}$ & Vostok & 2587 & & 9.5 \\
\hline
\end{tabular}

Correlation is based on major and trace elements by Kohno et al. (2004) $D$ value is calculated based on Perkins et al. (1995) with $\mathrm{Fe}, \mathrm{Ca}, \mathrm{Ti}, \mathrm{Mg}, \mathrm{Mn}$ and $\mathrm{K}$ $D$ values in italic letters are for tephra layers associated with South Sandwich Islands

Italic letters for Dome Fuji is based on the correlation with Vostok

inclusions in other grains such as plagioclase or volcanic glass.

According to the geochemical analysis and Curie temperature measurements, titanomagnetite in the volcanic ash particles was considered to have ulvospinel content of $0.2-0.35$. In addition to the above-mentioned granulometry based on FORC diagrams, conventional biplots such as Day plots could be used to understand the mixture of magnetic minerals with various domain states. Dunlop (2002a, b) developed comprehensive theory on Day plot covering superparamagnetic (SP), single-domain (SD), PSD and MD titanomagnetite. In Fig. 9, our data (solid circles) were plotted together with the data points measured by Day et al. (1977) for variable size fractions of titanomagnetite with chemical compositions of TM0, TM20, TM40 and TM60. Numbers marked beside red circles are mean size of TM40, which is roughly comparable to the chemical composition to the studied material. It should be noted that titanomagnetite grains used by Day et al. (1977) is crushed and unannealed. Crushed magnetite grains tend to show much higher $M_{\mathrm{rs}} / M_{\mathrm{s}}$ values and lower $H_{\mathrm{cr}} / H_{\mathrm{c}}$ values than the same size fractions with annealing (e.g., Dunlop 2002a).

Thick and thin solid lines are mixing curves for SD and MD magnetites, whereas thick broken curve is the mixing curve for titanomagnetite with chemical composition of TM60 (Dunlop 2002a). Note that most of the data points of this study are significantly away from the mixing curves for magnetite and those for the size fractions of titanomagnetites measured by Day et al. (1977), whereas the mixing curve of TM60 is touching some of the data points of this study, which is also touching two data points for TM40 size fraction $0.95 \mu \mathrm{m}$ on the upper left and $\sim 20 \mu \mathrm{m}$ on the lower bottom. Considering the interpretation of FORC diagrams, the magnetic mineral is primarily the mixture of PSD and SD titanomagnetite grains. Thus, the mixture of magnetic minerals should be right of thick solid curve and might be slightly left of thick broken curve. Additional SP contribution may shift the data points to the right of thick broken curve and slightly downward (Dunlop 2002a, b). Based on the calculation of thermally activated loops, Lanci and Kent (2003) also suggested that data points for SP particles on Day plot can be shifted further to the right and slightly downward depending on the volume and anisotropy distributions.

Wang and Van der Voo (2004) proposed a plot of $M_{\mathrm{rs}} / M_{\mathrm{s}}$ versus $H_{\mathrm{c}}$ (see Fig. 9b) to discriminate magnetic hysteresis properties of titanomagnetites in oceanic basalts. Dunlop (2002a) also noted that $M_{\mathrm{rs}} / M_{\mathrm{s}}$ and $H_{\mathrm{c}}$ respond to the mixing of size fractions of magnetic grains linearly, whereas $H_{\mathrm{cr}}$ respond nonlinearly. Thus, it is expected that the plot of $M_{\mathrm{rs}} / M_{\mathrm{s}}$ versus $H_{\mathrm{c}}$ for a suite of samples with the same chemical composition may follow a linear trend. In Fig. 9b, it should be noted that the trend for TM40 or TM20 by Day et al. (1977) is well below the trend of samples measured in this study (solid broken line). The difference might be accommodated by 


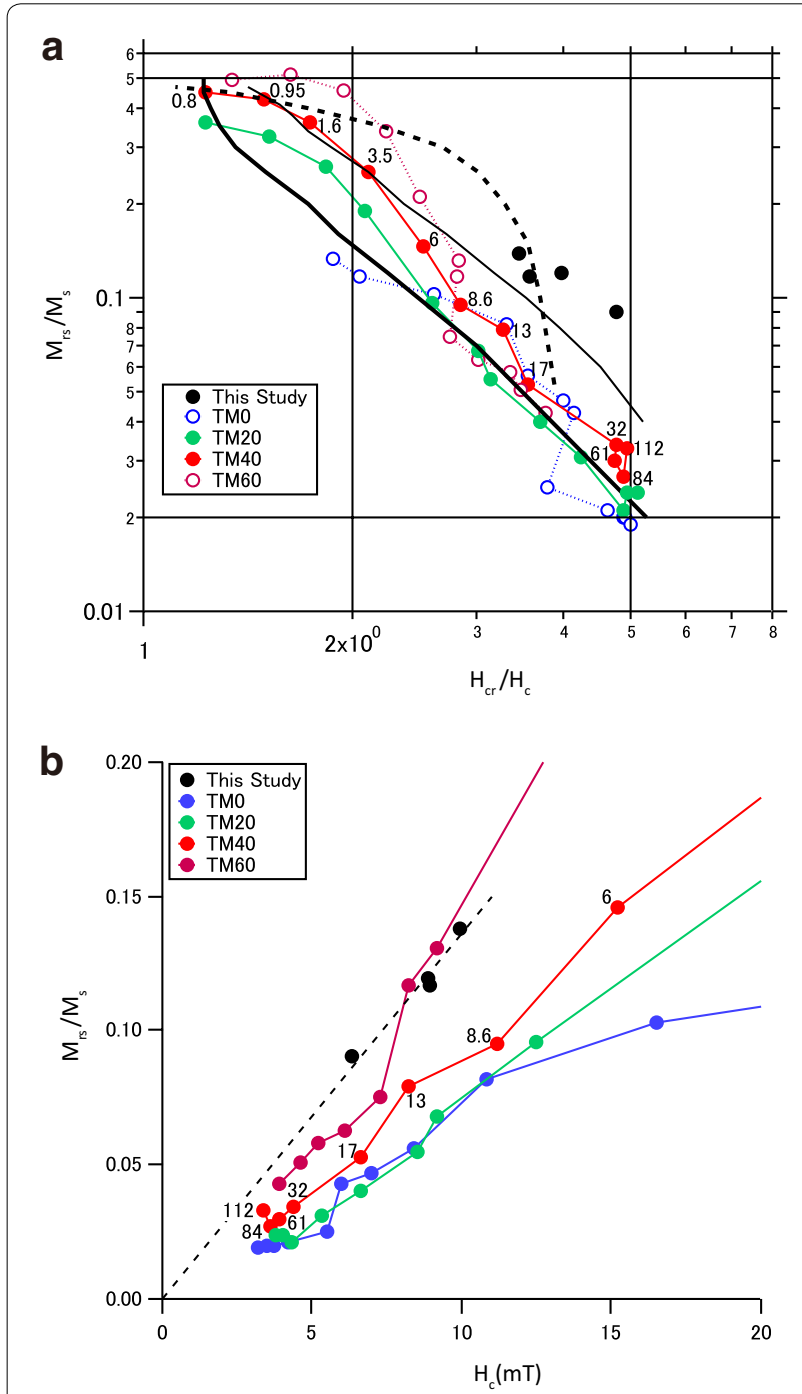

Fig. 9 a Day plot for this study (solid circles, which is basically the same as Fig. 5 d. Colored symbols are from Day et al. (1977) for pure magnetite (open blue circles), TM20 (solid green circles), TM40 (solid red circles) and TM60 (open purple circles). Thick (thin) black curve is theoretical mixing line of SD and MD magnetite by Dunlop (2002b) for case 2 and case 3 in his Fig. 2. Numbers on the sides of red circles are size of particles prepared by Day et al. (1977) for TM40. Thick broken line is a mixing curve of SD and MD titanomagnetite with TM60 composition (a curve in Figure 10 of Dunlop 2002a). b $M_{r s} / M_{s}$ versus $H_{c}$ plot proposed by Wang and Van der Voo (2004). Symbols are the same as Fig. 9a. Broken line is the fit through the origin for the data in this study (solid circles)

the effect of the presence of SP magnetic particles, which may shift data points to the left and slightly downward on the diagram. Although SP contribution of meteoric smoke in ice samples from Greenland and Antarctica has been pointed out (Lanci and Kent 2006; Lanci et al. 2007), the samples used for rock magnetic analyses in this study may not contain these particles due to the extraction process employed. The contribution of SP particles suggested by the rock magnetic parameters might be originated from inclusions in mineral grains and/or volcanic glasses.

\section{Detection of ash with LTS-SQUID gradiometer}

Peak value of $152 \mathrm{pT}$ for the measurement of model half-cylinder sample and that of $6.6 \mathrm{pT}$ for the theoretical curve suggest that the total magnetic moment for the measurement is estimated to be $3.0 \times 10^{-8} \mathrm{~A} \mathrm{~m}^{2}$. Magnetization of JARE54-ASH3-1 after acquisition of IRM at $25 \mathrm{mT}$ is $1.0 \times 10^{-2} \mathrm{~A} \mathrm{~m}^{2} / \mathrm{kg}$ (Fig. $5 \mathrm{c}$ ), so the estimated amount of material in the modeled sample is $3.0 \mathrm{mg}$. This is much smaller than the total volcanic particle weight of $9 \mathrm{mg}$ extracted from JARE54-ASH3 and mixed with epoxy glue to make the thin half-cylinder model sample. The discrepancy might be caused by the inhomogeneity within JARE54-ASH3 block sample in magnetization, larger distance of sensor to sample than calculated and/ or heterogeneous distribution of volcanic particles within half-cylinder sample mixed with epoxy glue. Lanci et al. (2001) pointed out the possibility of rotation of magnetic grains by meting of surrounding ice by the heat caused by electromagnetic induction at the time of IRM acquisition with a pulsed magnetic field. However, this may not be the case for this study, because we used static DC magnetic field for the acquisition of IRM.

It is important to know the detection limit of volcanic ash with the gradiometer. Average noise level for $Z$ axis gradiometer is $0.6 \mathrm{pT}$. Theoretical response curve of halfcylinder of uniform magnetization with total magnetic moment of $1.3 \times 10^{-9} \mathrm{~A} \mathrm{~m}^{2}$ in $X$ axis (radius $29 \mathrm{~mm}$, thickness $1 \mathrm{~mm}$ ) shows peak value of about $6.6 \mathrm{pT}$ (Fig. 8b; red curve). From these values, detection limit of magnetic moment can be calculated as $\sim 1.2 \times 10^{-10} \mathrm{~A} \mathrm{~m}^{2}$ for a thickness of $1 \mathrm{~mm}$. Corresponding detection limit of magnetization is $9.2 \times 10^{-5} \mathrm{~A} / \mathrm{m}$. With decreasing distance between sample and sensor from 9 to $6,3,1$ and $0.5 \mathrm{~mm}$, calculated peak magnetic field value increases to 15,53 , 184 and 277 pT, respectively (Fig. 10). These peak values correspond to detection limit of magnetic moment of $5.3 \times 10^{-11}, 1.4 \times 10^{-11}, 4 \times 10^{-12}$ and $2.7 \times 10^{-12} \mathrm{~A} \mathrm{~m}^{2}$ for a uniformly magnetized half-cylinder shaped sample with a thickness of $1 \mathrm{~mm}$. As the volume of the sample is $1.32 \mathrm{cc}$, corresponding magnetization is calculated as $4.0 \times 10^{-5}, 1.1 \times 10^{-5}, 3.0 \times 10^{-6}$ and $2.1 \times 10^{-6} \mathrm{~A} / \mathrm{m}$, respectively. 2G superconducting rock magnetometer (SRM) has a total magnetic moment noise level of about $2 \times 10^{-12} \mathrm{~A} \mathrm{~m}^{2}$ at GSJ. Considering the volume of the sample of $1.32 \mathrm{cc}$ for a half-cylinder with a thickness of $1 \mathrm{~mm}$, corresponding magnetization is calculated as $1.5 \times 10^{-6} \mathrm{~A} / \mathrm{m}$. Thus, the detection limit of volcanic ash layer with the current gradiometer system could be 


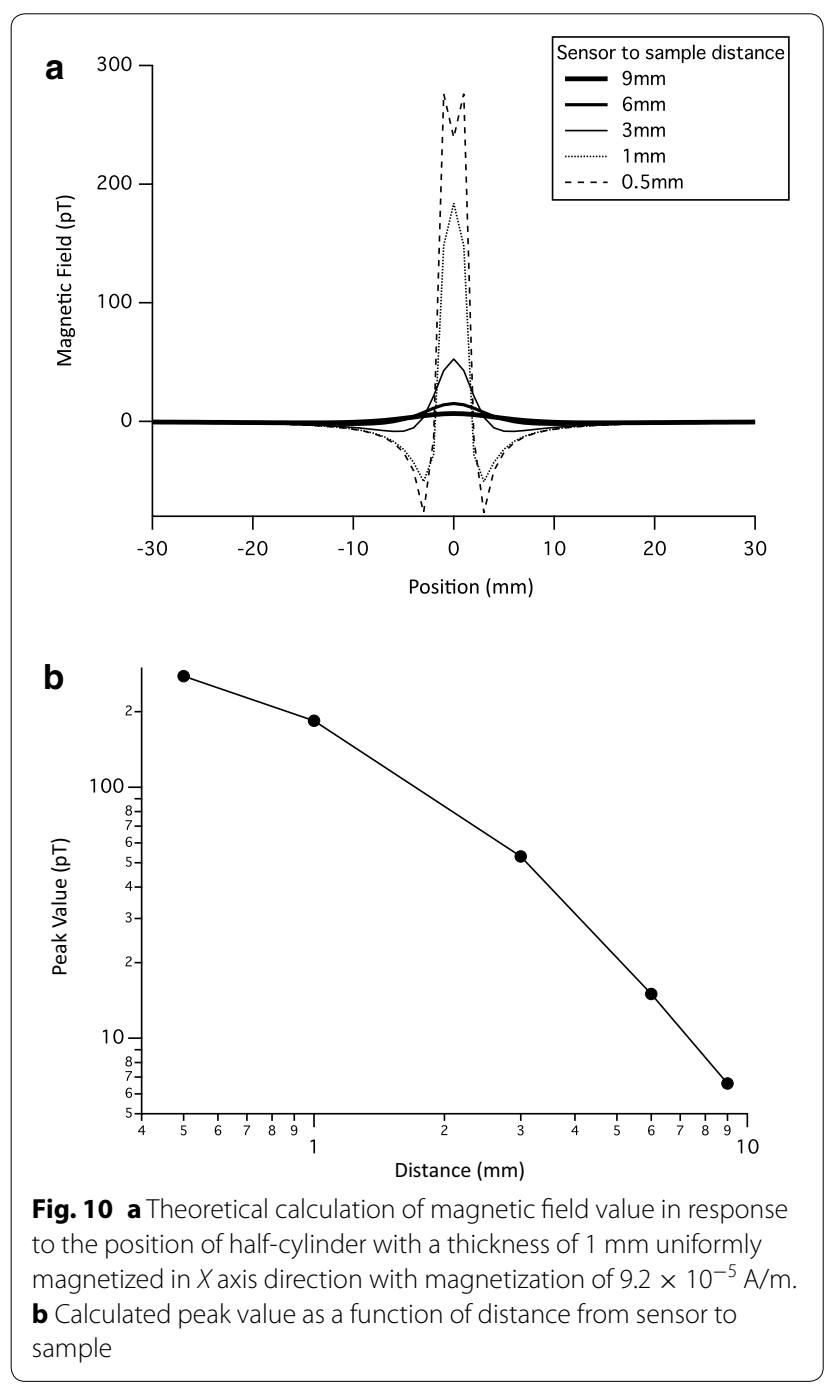

improved to the level of SRM by reducing the sampleto-sensor distance down to $0.5 \mathrm{~mm}$. Further improvements could be realized by increasing the stacking time and improvements in the magnetic shielding since the door of the magnetic shield room was open during our experiments.

\section{Conclusions}

Ice block samples of tephra-bearing layer with volcanic ash were collected from Nansen Ice Field south of the Sør Rondane Mountains, Antarctica. Threedimensional distributions of volcanic ash particles were imaged with microfocus X-ray CT. The volcanic ash particles have grain size of $\sim 50 \mu \mathrm{m}$, and the chemical composition of the matrix glass was found to belong to a low-K basaltic andesite group. The ash particles include microphenocrysts of plagioclase, orthopyroxene, clinopyroxene and $\mathrm{Fe}-\mathrm{Ti}$ oxide mineral. Considering the chemical composition, grain size and stronger westerly jet steam in the lower stratosphere of circum Antarctic region, the South Sandwich Islands could be the source area providing the analyzed volcanic ash particles. Correlations with tephra layers associated with South Sandwich Islands in EPICA-Dome C, Vostok and Dome Fuji ice cores show high similarity.

Magnetic mineral in the volcanic particles is considered to be titanomagnetite with ulvospinel content of $0.2-0.35$. Rock magnetic granulometry based on magnetic hysteresis properties including FORC analysis and biplots such as Day plot indicates that the volcanic particles are the mixture of PSD titanomagnetite, SD (titano) magnetite and SP (titano) magnetite with possible minor amount of MD titanomagnetite.

Magnetic signal of Antarctic ice block samples were measured in natural state with the gradiometer. Magnetic signal could be detected for ice block samples from JARE-ASH1 and JARE-ASH3 with volcanic ash content of 0.1-0.2 wt\%. After magnetized with DC magnetic field of $25 \mathrm{mT}$, magnetic signal could be detected for all the samples including the one with invisible amount of tephras with concentration of $0.007 \mathrm{wt} \%$. With the noise level of $0.6 \mathrm{pT}$ for $Z$ axis gradiometer and sensor-to-sample distance of $9 \mathrm{~mm}$, detection limit of magnetization was calculated as $\sim 9 \times 10^{-5} \mathrm{~A} / \mathrm{m}$ for half-cylinder with radius of $29 \mathrm{~mm}$ and thickness of $1 \mathrm{~mm}$. The detection limit could be improved down to $\sim 2 \times 10^{-6} \mathrm{~A} / \mathrm{m}$ by reducing the sensor-to-sample distance to $0.5 \mathrm{~mm}$ and further by increasing stacking time with improved magnetic shielding.

\section{Additional files}

Additional file 1. Rotation movie on ice sample JARE54-ASH1-2 by micro focus X-ray CT scan. Darker pixels are less dense (air). Red pixels correspond to particles with density higher than ice.

Additional file 2. Rotation movie on ice sample JARE54-ASH2-2 by micro focus X-ray CT scan. Darker pixels are less dense (air). Red pixels correspond to particles with density higher than ice.

Additional file 3. Rotation movie on ice sample JARE54-ASH3-2 by micro focus X-ray CT scan. Darker pixels are less dense (air). Red pixels correspond to particles with density higher than ice.

Additional file 4. Backscattered Electron Images (BEls; each image area is a square, $500 \mu \mathrm{m}$ each side) of volcanic ash particles extracted from tephra-bearing ice block samples with analyzed points (red numbers with arrows) for major element concentrations with EPMA.

Additional file 5: Table S1. Table of major element concentrations for the points in BEls (Suppl. 4). No. corresponds to each analyzed point. Abbreviations for phase are as follows; PI: plagioclase, MG: matrix glass, Mt: magnetite, Px: pyroxene, FeS: iron sulfide. Bold letters are mean and standard deviation for each phase. Analyzed points with mixed phases are not included in the table.

\section{Abbreviations}

AC: alternating current; AF: alternating field; ARM: anhysteretic remanent magnetization; BEl: backscattered electron image; Day plot: biplot of magnetic hysteresis parameters $M_{\mathrm{rs}} / M_{\mathrm{s}}$ versus $H_{\mathrm{cr}} / H_{\mathrm{c}}$ after Day et al. (1977); DC: direct current; EPMA: electron probe microanalyzer; FORC: first-order reversal curve; 
GSJ: Geological Survey of Japan; IRM: isothermal remanent magnetization; KIT:

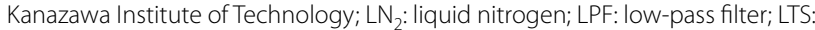
low-temperature superconductor; MD: multi-domain; NIPR: National Institute of Polar Research of Japan; NRM: natural remanent magnetization; PSD: pseudo-single-domain; SD: single-domain; SP: superparamagnetic; SIRM: saturation isothermal remanent magnetization; SQUID: superconducting quantum interference device; VARIFORC: variable FORC analysis proposed by Egli (2013); $\mathrm{X}$-ray CT: $\mathrm{X}$-ray computed tomography.

\section{Authors' contributions}

$\mathrm{HO}$ planned the project and prepared the manuscript for the most part. IM measured geochemistry of volcanic ash and prepared the manuscript on geochemistry and volcanic ash. JK contributed to SQUID gradiometer measurement setup, data analysis and manuscript. YS and MF conducted SQUID gradiometer measurements. NI planned and collected Antarctic tephrabearing ice samples. TM collected Antarctic tephra-bearing ice samples. TM conducted X-ray CT scan. YY planned X-ray CT scan, conducted a part of the rock magnetic experiment and prepared the manuscript on rock magnetism. All authors read and approved the final manuscript.

\section{Author details}

${ }^{1}$ Research Institute of Geology and Geoinformation, Geological Survey of Japan, AIST, Central 7, 1-1-1 Higashi, Tsukuba 305-8567, Japan. ${ }^{2}$ Research Institute of Earthquake and Volcano Geology, Geological Survey of Japan, AIST, Central 7, 1-1-1 Higashi, Tsukuba 305-8567, Japan. ${ }^{3}$ Applied Electronics Laboratory, Kanazawa Institute of Technology, 3 Amaike, Kanazawa 920-1331, Japan. ${ }^{4}$ National Institute of Polar Research, 10-3 Midori-cho, Tachikawa, Tokyo 190-8518, Japan. ${ }^{5}$ Department of Earth and Planetary Science, Graduate School of Science, The University of Tokyo, 7-3-1 Hongo, Bunkyo-ku, Tokyo 113-0033, Japan. ${ }^{6}$ Center for Advanced Marine Core Research, Kochi University, B200 Monobe, Nankoku, Kochi 783-8502, Japan.

\section{Acknowledgements}

Ayako Katayama helped rock magnetic measurements at Geological Survey of Japan, AIST. Miki Kawabata fabricated the SQUID gradiometers at Applied Electronics Laboratory, KIT. Hirokuni Oda was supported by JSPS Grant-in-Aid for Scientific Research No. 24654166. Part of the measurements were conducted with the equipments of GSJ-Lab.

\section{Competing interests}

The authors declare that they have no competing interests.

Received: 30 July 2015 Accepted: 17 February 2016

Published online: 09 March 2016

\section{References}

Basile I, Petit JR, Touron S, Grousset FE, Barkov N (2001) Volcanic layers in Antarctic (Vostok) ice cores: Source identification and atmospheric implications. J Geophys Res 106:31915-31931

Bender ML, Floch G, Chappellaz J, Suwa M, Barnola J-M, Blunier T, Dryfus G, Jouzel J, Parrenin F (2006) Gas age-ice age differences and the chronology of the Vostok ice core, 0-100 ka. J Geophys Res 111:D21115. doi:10.1 029/2005JD006488

Cassidy W, Harvey R, Schutt J, Delisle G, Yanai K (1992) The meteorite collection sites of Antarctica. Meteoritics 27:490-525

Dadic R, Mullen PC, Schneebeli M, Brandt RE, Warren SG (2013) Effects of bubbles, cracks, and volcanic tephra on the spectral albedo of bare ice near the Transantarctic Mountains: implications for sea glaciers on Snowball Earth. J Geophys Res Earth Surf 118:1-19. doi:10.1002/jgrf.20098

Day R, Fuller M, Schmidt VA (1977) Hysteresis properties of titanomagnetites: grain-size and compositional dependence. Phys Earth Planet Inter 13:260-267

Dunber NW, Kurbatov AV (2011) Tephrochronology of the Siple Dome ice core, West Antarctica: correlations and sources. Quat Sci Rev 30:1602-1614

Dunlop DJ (2002a) Theory and application of the Day plot $\left(M_{\mathrm{rs}} / M_{\mathrm{s}}\right.$ versus $\left.H_{\mathrm{cr}} / H_{\mathrm{c}}\right)$ 1. Theoretical curves and tests using titanomagnetite data. J Geophys Res 107(B3):2056. doi:10.1029/2001JB000486
Dunlop DJ (2002b) Theory and application of the Day plot $\left(M_{\mathrm{rs}} / M_{\mathrm{s}}\right.$ versus $\left.H_{\mathrm{Cr}} / H_{\mathrm{c}}\right)$ 2. Application to data for rocks, sediments, and soils. J Geophys Res 107(B3):2057. doi:10.1029/2001JB000487

Egli R (2013) VARIFORC: an optimized protocol for the calculation of nonregular first-order reversal curve (FORC) diagrams. Glob Planet Change 110:302-320. doi:10.1016/j.gloplacha.2013.08.003

Funaki M (1990) Note on the natural remanent magnetizations of dirt-ice layers collected from the bare ice field in east Antarctica. Nankyoku Siryo (Antarct Record) 34:130-138 (in Japanese with English abstract)

Funaki M, Nagata T (1985) A report of natural remanent magnetization of dirt ice layers collected from Allan Hills, Southern Victoria Land, Antarctica. Mem Natl Inst Polar Res Spec Issue 39:209-213

Funaki M, Sakai H (1997) Natural remanent magnetization of dirt-ice layers collected from Antarctica. Seppyo 59:95-100 (in Japanese)

Gill J (1981) Orogenic andesite and plate tectonics. Springer, New York

Harrison RJ, Feinberg JM (2008) FORCinel: an improved algorithm for calculating first-order reversal curve distributions using locally weighted regression smoothing. Geochem Geophys Geosyst 9:Q05016. doi:10.1029/200 $8 \mathrm{GC001987}$

Imae N, Debaille V, Akada Y, Debouge W, Goderis S, Hublet G, Mikouchi T, Van Roosbroek N, Yamaguchi A, Zekollari H, Claeys P, Kojima H (2015) Report of the JARE-54 and BELARE 2012-2013 joint expedition to collect meteorites on the Nansen Ice Field, Antarctica. Antarct Rec 59:38-72

Jacox JM, Ketchen MB (1981) Planar coupling scheme for ultra low noise DC SQUID. IEEE Trans Magn MAG-17:400-403

Jouzel J (2013) A brief history of ice core science over the last 50 yr. Clim Past 9:2525-2547. doi:10.5194/cp-9-2525-2013

Kawai J, Shimozu T, Kawabata M, Uehara G, Adachi Y, Miyamoto M, Ogata H (2005) Fabrication and characterization of integrated 9-channel superconducting quantum interference device magnetometers on a single chip. IEEE Trans Appl Supercond 15:821-824

Kohno M, Fujii Y, Hirata T (2004) Chemical composition of volcanic glasses in visible tephra layers found in a 2503 m deep ice core from Dome Fuji, Antarctica. Ann Glaciol 39:576-584

Kroll JH, Cross ES, Hunter JF, Pai S, TREX XII, TREX XI, Pai S, Wallace LMM, Croteau PL, Jayne JT, Worsnop DR, Heald CL, Murphy JG, Frankel SL (2015) Atmospheric evolution of sulfur emissions from Kilauea: real-time measurements of oxidation, dilution, and neutralization within a volcanic plume. Environ Sci Technol 49:4129-4137. doi:10.1021/es506119x

Lanci L, Kent DV (2003) Introduction of thermal activation in forward modeling of SD hysteresis loops and implications for the interpretation of the Day diagrams. J Geophys Res 108(B3):2142. doi:10.1029/2001JB000944

Lanci L, Kent DV (2006) Meteoric smoke fallout revealed by superparamagnetism in Greenland ice. Geophys Res Lett 33:L13308. doi:10.1029/200 6GL026480

Lanci L, Kent DV, Biscaye PE, Bory A (2001) Isothermal remanent magnetization of Greenland ice: preliminary results. Geophys Res Lett 28(8):1639-1642

Lanci L, Kent DV, Biscaye PE (2007) Meteoric smoke concentration in the Vostok ice core estimated from superparamagnetic relaxation and some consequences for estimates of Earth accretion rate. Geophys Res Lett 34:L10803. doi:10.1029/2007GL029811

Lanci L, Delmonte B, Kent DV, Maggi V, Biscaye PE, Petit J-R (2012) Magnetization of polar ice: a measurement of terrestrial dust and extraterrestrial fallout. Quat Sci Rev 33:20-31. doi:10.1016/j.quascirev.2011.11.023

Landais A, Dreyfus G, Capron E, Pol K, Loutre MF, Raynaud D, Lipenkov VY, Arnaud L, Masson-Delmotte V, Paillard D, Jouzel J, Leuenberger M (2012) Towards orbital dating of the EPICA Dome C ice core using $802 / \mathrm{N} 2$. Clim Past 8:191-203. doi:10.5194/cp-8-191-2012

Lattard D, Engelmann R, Kontny A, Sauerzapf U (2006) Curie temperatures of synthetic titanomagnetites in the Fe-Ti-O system: effects of composition, crystal chemistry, and thermomagnetic methods. J Geophys Res 111:B12S28. doi:10.1029/2006JB004591

Lazzara M, Dworak R, Santek D, Hoover BT, Velden CS, Key JR (2014) Highlatitude atmospheric motion vectors from composite satellite data. J Appl Meteorol Clim 53:534-547. doi:10.1175/JAMC-D-13-0160.1

Leat PT, Smellie JL, Millar IL, Larter RD (2003) Magmatism in the South sandwich arc. Geol Soc Lond Spec Publ 219:285-313. doi:10.1144/GSL. SP.2003.219.01.14

Misawa K, Kohno M, Tomiyama T, Noguchi T, Nakamura T, Nagao K, Mikouchi T, Nishiizumi K (2010) Two extraterrestrial dust horizons found in the 
Dome Fuji ice core, East Antarctica. Earth Planet Sci Lett 289:287-297. doi:10.1016/..epsl.2009.11.016

Mori T, Kato K (2013) Sulfur dioxide emissions during the 2011 eruption of Shinmoedake volcano, Japan. Earth Planets Space 65:573-580. doi:10.5047/eps.2013.04.005

Naraoka H, Yanai K, Fujita S (1991) Dirt bands in the bare ice area around the Sor Rondane Mountains in Queen Maud Land, Antarctica. Nankyoku Siryo (Antarct Rec) 35:47-55 (in Japanese with English abstract)

Narcisi B, Petit JR, Delmonte B, Basile-Doelsch I, Maggi V (2005) Characteristics and sources of tephra layers in the EPICA-Dome $C$ ice record (East Antarctica): implications for past atmospheric circulation and ice core stratigraphic correlations. Earth Planet Sci Lett 239:253-265

Narcisi B, Petit JR, Delmonte B (2010) Extended East Antarctic icecore tephrostratigraphy. Quat Sci Rev 29:21-27. doi:10.1016/j. quascirev.2009.07.009

Nishio F, Katsushima T, Ohmae H (1985) Volcanic ash layers in bare ice areas near the Yamato Mountains, Dronning Maud Land and the Allan Hills, Victoria Land, Antarctica. Ann Glaciol 7:34-41

Okazaki R, Noguchi T, Tsujimoto S, Tobimatsu Y, Nakamura T, Ebihara M, Itoh S, Nagahara H, Tachibana S, Terada K, Yabuta H (2015) Mineralogy and noble gas isotopes of micrometeorites collected from Antarctic snow. Earth Planets Space 67:90. doi:10.1186/s40623-015-0261-8

Palais JM, Kyle PR, Mosley-Thompson E, Thomas E (1987) Correlation of a 3200 year old tephra in ice cores from Vostok and South Pole stations, Antarctica. Geophys Res Lett 14:804-807

Palais JM, Petit JR, Lorius C, Korotkevich YS (1989) Tephra layers in the Vostok ice core: 160,000 years of southern hemisphere volcanism. Antarct J Rev 24:98-100

Parrenin F, Petit JR, Masson-Delmotte V, Wolff E, Basile-Doelsch I, Jouzel J, Lipenkov V, Rasmussen SO, Schwander J, Severi M, Udisti R, Veres D, Vinther BM (2012) Volcanic synchronisation between the EPICA Dome C and Vostok ice cores (Antarctica) 0-145 kyr BP. Clim Past 8:1031-1045. doi:10.5194/cp-8-1031-2012
Perkins ME, Nash WP, Brown FH, Fleck RJ (1995) Fallout tuffs of Trapper Creek, Idaho: a record of Miocene explosive volcanism in the Snake River Plain volcanic province. GSA Bull 107:1484-1506

Prata AT, Siems ST, Manton MJ (2015) Quantification of volcanic cloud top heights and thicknesses using A-train observations for the 2008 Chaiten eruption. J Geophys Res Atmos 120:2928-2950. doi:10.1002/201 4JD022399

Roberts AP, Heslop D, Zhao X, Pike CR (2014) Understanding fine magnetic particle systems through use of first-order reversal curve diagrams. Rev Geophys 52:557-602. doi:10.1002/2014RG000462

Storey M, Roberts R, Saidin M (2012) Astronomically calibrated ${ }^{40} \mathrm{Ar} /{ }^{39} \mathrm{Ar}$ age for the Toba supereruption and global synchronization of late Quaternary records. Proc Natl Acad Sci 109:18684-18688. doi:10.1073/ pnas. 1208178109

Suzuki T (1983) A theoretical model for dispersion of tephra. In: Shimozuru D, Yokoyama I (eds) Arc volcanism: physics and tectonics. Terrapub, Tokyo, pp 95-113

Suzuki YJ, Koyaguchi T (2013) 3D numerical simulation of volcanic eruption clouds during the 2011 Shinmoe-dake eruptions. Earth Planets Space 65:581-589. doi:10.5047/eps.2013.03.009

Wang D, Van der Voo R (2004) The hysteresis properties of multidomain magnetite and titanomagnetite/titanomaghemite in mid-ocean ridge basalts. Earth Planet Sci Lett 220:175-184. doi:10.1016/S0012-821X(04)00052-4

Watanabe O, Kamiyama K, Motoyama H, Fujii Y, Shoji H, Satou K (1999) The paleoclimate record in the ice core at Dome Fuji station, East Antarctica. Ann Glaciol 29:176-178

\section{Submit your manuscript to a SpringerOpen ${ }^{\circ}$ journal and benefit from:}

- Convenient online submission

- Rigorous peer review

- Immediate publication on acceptance

- Open access: articles freely available online

- High visibility within the field

- Retaining the copyright to your article

Submit your next manuscript at $\boldsymbol{\wedge}$ springeropen.com 